OPEN ACCESS

Edited by:

Antonio Pierini,

University of Perugia, Italy

Reviewed by:

Leo Luznik,

Johns Hopkins University,

United States

Alice Bertaina,

Stanford University, United States

*Correspondence:

Luca Vago

vago.luca@hsr.it

†These authors have contributed equally to this work

Specialty section:

This article was submitted to Alloimmunity and Transplantation,

a section of the journal

Frontiers in Immunology

Received: 04 October 2019

Accepted: 20 January 2020

Published: 25 February 2020

Citation:

Rovatti PE, Gambacorta V, Lorentino F, Ciceri F and Vago $L$ (2020) Mechanisms of Leukemia Immune Evasion and Their Role in

Relapse After Haploidentical Hematopoietic Cell Transplantation.

Front. Immunol. 11:147.

doi: 10.3389/fimmu.2020.00147

\section{Mechanisms of Leukemia Immune Evasion and Their Role in Relapse After Haploidentical Hematopoietic Cell Transplantation}

\author{
Pier Edoardo Rovatti ${ }^{1,2+}$, Valentina Gambacorta ${ }^{1,3+}$, Francesca Lorentino ${ }^{2 \dagger}$, Fabio Ciceri ${ }^{2,4}$ \\ and Luca Vago ${ }^{1,2 *}$ \\ ' Unit of Immunogenetics, Leukemia Genomics and Immunobiology, IRCCS San Raffaele Scientific Institute, Milan, Italy, \\ ${ }^{2}$ Hematology and Bone Marrow Transplantation Unit, IRCCS San Raffaele Scientific Institute, Milan, Italy, ${ }^{3}$ Unit of \\ Senescence in Stem Cell Aging, Differentiation and Cancer, San Raffaele Telethon Institute for Gene Therapy, IRCCS San \\ Raffaele Scientific Institute, Milan, Italy, ${ }^{4}$ Vita-Salute San Raffaele University, Milan, Italy
}

Over the last decade, the development of multiple strategies to allow the safe transfer from the donor to the patient of high numbers of partially HLA-incompatible T cells has dramatically reduced the toxicities of haploidentical hematopoietic cell transplantation (haplo-HCT), but this was not accompanied by a similar positive impact on the incidence of post-transplantation relapse. In the present review, we will elaborate on how the unique interplay between HLA-mismatched immune system and malignancy that characterizes haplo-HCT may impact relapse biology, shaping the selection of disease variants that are resistant to the "graft-vs.-leukemia" effect. In particular, we will present current knowledge on genomic loss of HLA, a relapse modality first described in haplo-HCT and accounting for a significant proportion of relapses in this setting, and discuss other more recently identified mechanisms of post-transplantation immune evasion and relapse, including the transcriptional downregulation of HLA class II molecules and the enforcement of inhibitory checkpoints between $T$ cells and leukemia. Ultimately, we will review the available treatment options for patients who relapse after haplo-HCT and discuss on how a deeper insight into relapse immunobiology might inform the rational and personalized selection of therapies to improve the largely unsatisfactory clinical outcome of relapsing patients.

Keywords: haploidentical allogeneic hematopoietic stem cell transplantation, relapse, immune escape, HLA, immune check point

\section{INTRODUCTION}

Allogeneic hematopoietic cell transplantation from haploidentical family members represents a promising solution to offer allogeneic HCT to virtually all patients with an indication to transplant, but lacking a fully compatible and/or rapidly available donor. However, from the immunological standpoint, haplo-HCT also represents the most challenging transplantation setting, counterpoising two largely HLA-incompatible immune systems and thus posing a severe risk of graft-vs.-host disease (GvHD) and immune rejection. To overcome this obstacle, over the last few decades, many strategies have been developed to improve the feasibility and safety of haploHCT $(1,2)$. In particular, two main haplo-HCT "philosophies" were progressively refined over 
the years: the ex vivo manipulation of the graft to deplete the most alloreactive cell subsets (3), eventually reinfusing them in a subsequent moment in combination with regulatory $\mathrm{T}$ cells $(4,5)$ or upon incorporation of safety switches (6-8), vs. the infusion of unmanipulated grafts, followed by administration of drugs capable of eliminating alloreactive cells in vivo $(9,10)$. Noticeably, some of these platforms have demonstrated remarkable success, leading to an exponential increase in the number of haplo-HCT performed worldwide $(11,12)$.

The development of innovative strategies to render haplo-HCT feasible was fueled by intensive research on the immunobiology of allo-HCT, leading to a number of observations that were later extended to other transplantation settings or even served as the foundation to explain the physiological metrics of immune responses to pathogens and tumors.

In the present review, we will present one of the most paradigmatic examples of this process by describing how investigation of mechanisms of relapse after haplo-HCT paved the way to understanding the interplay between transplanted immune system and tumor also in other transplantation settings and, importantly, to the development of new rationales for relapse therapy.

\section{TUMOR-INTRINSIC MECHANISMS OF RELAPSE}

Seminal studies conducted by the Seattle group more than 25 years ago led to the identification of donor-derived $\mathrm{T}$ cells as one of the major drivers of the graft-vs.-leukemia $(\mathrm{GvL})$ effect (13). It is thus no surprise that all the best-characterized tumorintrinsic mechanisms of immune evasion and relapse after alloHCT have as a final output the abrogation of interactions between $\mathrm{T}$ cells and the tumor. This can occur either because leukemia cells become "invisible" to patrolling T cells, for instance through genetic or epigenetic alterations in the antigen processing and presenting machinery, or because they enact mechanisms to render the encounter ineffectual, as when inhibitory immune checkpoints are enforced (Figure 1).

\section{Genomic Loss of HLA}

Alterations in the expression and functionality of HLA class I and II molecules have long been characterized in solid tumors, underlining also in this setting the importance of T cell-mediated responses in shaping tumor immunogenicity (14).

Interestingly, in hematological tumors, and acute myeloid leukemia (AML) in particular, alterations in the HLA region are quite uncommon, especially at the time of diagnosis $(15,16)$. This feature is critical, since the donor T cell-mediated GvL effect of allo-HCT mostly depends on the HLA molecule expression on the surface of leukemic cells. As part of the antigen-presenting machinery, HLA molecules serve as restriction elements for minor histocompatibility antigens and tumor-associated antigens or, when incompatible, as direct targets of primary alloreactivity. In haplo-HCT especially, where an entire HLA haplotype is mismatched between patient and donor, $\mathrm{T}$ cell-mediated alloreactivity converges against the incompatible molecules that rapidly become the immunodominant GvL targets.

Given this fundamental role of HLAs in the biology of haplo$\mathrm{HCT}$, it is reasonable that a possible getaway for malignant cells to escape the bottleneck of immunological pressure might be to exploit alterations in the HLA locus, mirroring what happens in solid tumors.

The first characterization of such a strategy being used in AML after haplo-HCT was provided nearly 10 years ago, when genomic loss of the mismatched HLA haplotype (from this point on referred to as "HLA loss") was first reported (17). Behind this discovery, there is a curious case of serendipity: While investigating intermediate-resolution genomic HLA typing of bone marrow aspirate samples as an alternative technique for the assessment of hematopoietic chimerism (18), our group encountered several cases of AML post-transplantation relapse that typed negative for the patient HLAs. Genomic HLA typing of leukemic blasts purified from these relapses confirmed the absence of all HLA class I and class II genes encoded on the mismatched patient-specific HLA haplotype. A deeper examination of this phenomenon was then carried out exploiting whole-genome single-nucleotide polymorphism (SNP) arrays, demonstrating loss of heterozygosity $(\mathrm{LOH})$ of chromosome $6 \mathrm{p}$ in the absence of copy number variations (CNVs), thus suggesting an event of acquired somatic uniparental disomy (aUPD). UPD has been described as a common chromosomal aberration in different tumor types, both solid and hematological (19-21). This genomic alteration consists of the loss of a chromosome region that is subsequently replaced by the homologous copy, resulting in acquired homozygosity of that region without the actual loss of genomic material. The consequences of this event can be diverse: We can witness an increase in the expression of oncogenes, loss of heterozygosity of mutated tumor-suppressors, or in this specific context, the loss of the HLA molecules not shared between donor and recipient, which represented the most immunodominant targets for donor $\mathrm{T}$ cell alloreactivity. In the case of HLA loss, the observed rearrangements had variable boundaries and extension in the different patients, but in most cases, encompassed the entire HLA region and, therefore, included all HLA class I and class II loci.

Ex vivo coculture of donor $\mathrm{T}$ cells with leukemic cells demonstrated that when HLA loss occurs, mutated blasts become completely invisible to donor $\mathrm{T}$ cells that were capable of recognizing them before transplantation, thus taking the upper hand over other clones and rapidly becoming the predominant population $(17,22)$. Documentation of HLA loss not only provides an explanation for how disease escaped a pre-existing control, but also contraindicates the infusion of additional donor $\mathrm{T}$ cells as a strategy to try to revert relapse, since also these cells would fail to find a target to attack.

Conversely, HLA loss variants that become invisible to donor $\mathrm{T}$ cell allorecognition could in principle still represent viable targets for alloreactive donor natural killer (NK) cells. Indeed, while the mechanism of aUPD does not reduce the overall surface levels of HLA class I molecules on the leukemia cell surface, thus avoiding to trigger "missing self" recognition by NK cells (23), 


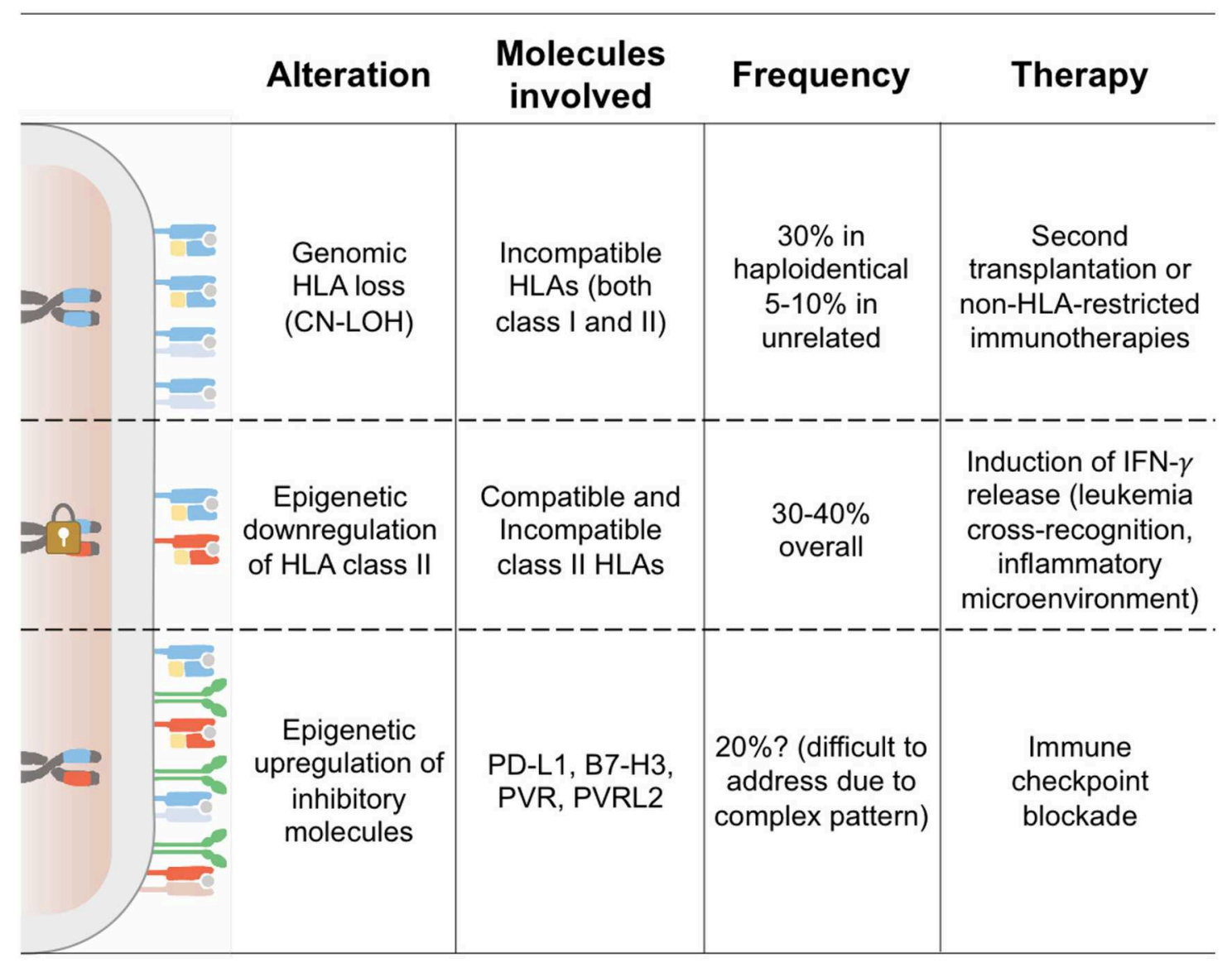

FIGURE 1 | Tumor-Intrinsic Mechanisms of Immune Evasion and Relapse. This cartoon summarizes the features of the three modalities of leukemia immune evasion and relapse after allo-HCT better characterized to date. Chromosomes indicate the HLA haplotype homo- or hetero-zygosity, showing in cyan the donor-recipient shared haplotype and in red the patient-specific incompatible haplotype. The padlock symbolizes epigenetic silencing of the HLA class II loci. On the cell surface, HLA class I molecules are shown as heterodimers of HLA and beta-2-microglobulin (in yellow), HLA class II as dimers of two transmembrane single-chain HLA molecules, and inhibitory ligands as green homodimers.

the HLA alleles that are lost by leukemia cells often also represent ligands for donor inhibitory KIRs (24). Nonetheless, HLA loss relapses still occur, and the biology at the basis of NK cell failure in preventing or controlling the emergence of HLA loss relapses needs to be investigated further. This is highly relevant from the translational standpoint, since an improved understanding of NK cell responses in the context of HLA loss could also serve as a springboard to design adoptive immunotherapy trials based on NK cells to treat, or even prevent, these relapse variants.

One of the most relevant open issues regarding HLA loss is understanding when the genetic alteration occurs, or in other terms, if an infinitesimally small immune-resistant clone exists before allo-HCT or not. To date, the molecular drivers of aUPD are poorly known. It has been demonstrated that an increased susceptibility for chromosomal breaks and the effects of DNA damage inducers, including chemotherapeutic agents, might lead to higher aUPD risk in tight proximity of mitotic recombination sites (20), jeopardizing those heavily treated patients who undergo the transplantation procedure after multiple lines of chemotherapy. However, there is also evidence that aUPD can also be a common finding in AML samples at the time of diagnosis, with a large study on 454 samples reporting aUPD frequency of $15-20 \%$. This alteration mainly affects specific chromosome arms, including 13q, 11p, and 11q (25). Of note in these reports, the involvement of the HLA region located in chromosome $6 \mathrm{p}$ is exceptional, with an estimated 3-4\% of myeloid malignancies characterized by HLA LOH at disease onset $(26,27)$.

Some suggestions on the biological origin of HLA loss relapses come from retrospective clinical studies. In the largest analysis on this topic performed to date (28), HLA loss relapses were shown to occur significantly later than their "classical" counterparts and to be strongly associated to allo-HCTs performed in an active disease stage. A possible explanation linking these two observations might be that patients transplanted with a sizable leukemia burden probably present also much higher intratumoral heterogeneity than those transplanted with minimal or even undetectable residual disease and are thus also more likely to carry a clone with HLA loss or with high predisposition to aUPD, which may then slowly but steadily grow in the subsequent months following transplantation. 
Soon after the initial description (17), a number of other studies reported cases of HLA loss relapses after haplo-HCT, with an incidence ranging between 20 and $40 \%$ of all relapses occurring in this setting $(22,29,30)$. Of interest, analysis of two different cohorts transplanted at our institution using the same haplo-HCT backbone and differing only in the use of antithymocyte globulin (31) or high-dose cyclophosphamide (32) as in vivo $\mathrm{T}$ cell-depleting agent showed superimposable frequency of HLA loss relapses, suggesting that regardless of the strategy used, a significant population of alloreactive $\mathrm{T}$ cells escapes the initial purging and is capable to mediate significant antileukemic immune pressure. Studies specifically focused on T cell-depleted haplo-HCTs are to date lacking, but available data from $\mathrm{T}$ cell replete platforms indicate that the frequency of HLA loss is directly associated to the number of T cells transferred as part of the graft or after that (28), thus suggesting that in "T cell naked" transplants, HLA loss might be a rare event and relapses might have different underlying biology.

Interestingly, there have been reports of HLA loss relapses occurring in other transplantation settings, in particular after mismatched unrelated donor HCT (33-36) and, less frequently, after matched unrelated donor HCT (36). Although these reports originate from small cohorts of patients and therefore cannot provide an accurate estimate of the actual incidence of HLA loss in these settings, they appear to indicate a lower incidence of the phenomenon as compared to haplo-HCT. We can speculate that this lower frequency might indicate that, when donorrecipient incompatibilities are fewer, $\mathrm{T}$ cell alloreactivity and GvL effect is less pronouncedly focused against incompatible HLAs and possibly outperformed by immunodominant minor histocompatibility antigens. Moreover, it should be considered that in the unrelated HCT setting, the incompatibilities are often not in cis on the same haplotype, meaning that losing one haplotype by aUPD might not be as effective in abrogating immune pressure as in the haplo-HCT setting. Finally, the relative contribution of mismatches at the different HLA loci in driving alloreactivity and the GvL effect is not entirely clear, and it may be possible that some, but not other, incompatibilities might be more potent in promoting immune escape by HLA loss. In conclusion, more studies regarding the characterization of relapses outside of the haploidentical setting are still needed, and the complete understanding of how the GvL effect and the strength of the selective pressure mediated by alloreactive T-cells influences and shapes the underlying biological mechanisms of relapse in these contexts is yet to be entirely dissected.

It has already been stated how the occurrence of this genomic alteration greatly impairs $\mathrm{T}$ cell allorecognition, prompting the need for a more personalized clinical management of these relapses. As a consequence, the acute leukemia working party (ALWP) of the European Society for Blood and Marrow Transplantation (EBMT) recently made recommendations for testing eventual HLA loss at the time of relapse before employing donor lymphocyte infusions (DLIs) (37). However, until recently, documentation of HLA loss at relapse required the presence of a considerable tumor burden to perform HLA typing of either unprocessed bone marrow samples or, when possible, sorted leukemic blasts (18). To overcome these limitations, we recently developed "HLA-KMR," a rapid, reliable, and economic assay based on quantitative PCR (qPCR) (38) that almost immediately became a commercially available diagnostic tool (GenDx, The Netherlands). The rationale of HLA-KMRs is to combine the detection of non-HLA-polymorphisms together with ad hoc qPCR reactions targeting the most common HLA allele groups. Therefore, in "classical" relapses, non-HLA and patient-specific HLA markers are concordantly positive, whereas the absence of HLA-specific signal indicates HLA loss relapse. This tool provides a sensitive method to detect HLA loss relapses event at early stages, allowing fast clinical decision-making and the use of a personalized therapeutic approach for every patient.

Finally, what should be the most appropriate therapeutic approach for HLA loss relapses occurring after haplo-HCT? Taking into consideration the mechanism and immunological consequences of this genomic alteration, a possible strategy could be a second haploidentical transplantation from an alternative donor, selected to target the remaining HLA haplotype. This originates from a unique situation, where donor $\mathrm{T}$ cells still share one haplotype with non-hematopoietic tissues, while being fully mismatched with the leukemic blasts, possibly providing an even stronger GvL effect (39). As a proof of concept, this approach was the one associated with the longest survival after relapse for patients experiencing HLA loss at our center (28) and might explain the superior outcome described by Imus and collaborators upon choosing donors with a different HLA-haplotype for second haplo-HCT (40). Unfortunately, a second allo-HCT is often not feasible in elderly or heavily pretreated patients, prompting further preclinical and clinical studies to treat HLA loss relapses using non-HLA-restricted immunotherapy approaches, including bispecific antibodies and chimeric antigen receptor (CAR)-modified T cells.

\section{Downregulation of HLA Class II Molecules}

Two very recent studies provided remarkable evidence that genomic haplotype loss is not the only strategy used by leukemic cells to alter their HLA assets and avoid detection by donor-derived $\mathrm{T}$ cells. In both studies, comparison of samples pairwise collected from patients before and after allo-HCT led to appreciate that in up to $40 \%$ of post-transplantation relapses, the surface expression of HLA class II molecules (HLA-DR, -DQ, and -DP) becomes virtually absent, and this translates to the failure of donor $\mathrm{T}$ cells primed against the original disease to recognize the relapse variants $(41,42)$. Supporting previous studies conducted in animal models (43), this evidence suggests that interactions between HLA class II molecules and CD4 T cells are necessary for a proficient GvL effect and that this non-redundant arm of the antitumor immunity represents a vulnerability that is easily exploited by leukemia to reemerge. It should be noted, however, that HLA class II expression is also emerging as a relevant prognostic parameter in a number of other malignancies. HLA class II negativity has in fact been linked to unfavorable outcome in patients diagnosed with germinal center B-cell like diffuse large B cell lymphoma $(44,45)$ and with microsatellite stable carcinomas (46). In a study performed on relapsed/refractory classical Hodgkin's lymphoma, in addition to the positivity for PD-L1, high surface expression of HLA class II molecules also 
correlated with a better response to the anti PD-1 monoclonal antibody nivolumab (47).

Coming back to leukemia post-transplantation relapses, similar to the previously described genomic HLA loss mechanism, in this case a higher dose of $\mathrm{T}$ cells infused with the graft is also associated with a higher likelihood of also experiencing this modality of relapse (41). However, different from haplotype loss, class II downregulation has to date been observed with similar frequencies in both HLA-compatible and incompatible transplants $(41,42)$. This observation suggests that the driver of this event might not be alloreactivity toward incompatible HLA class II molecules, but rather against their presented repertoire of tumor-specific antigens and minor histocompatibility antigens. Recently, in silico studies convincingly showed that the number of minor histocompatibility antigens that are presented by HLA class II molecules surpasses its HLA class I counterpart by more than one logarithm $(48,49)$, suggesting that in the unrelated donor setting, immune reactivity against minors might be even more potent than the one against the few incompatible HLA molecules.

Of note, in both studies that first described HLA class II downregulation as an immune escape modality, in-depth genetic profiling of the relapsed leukemia found no evidence of mutations in HLA genes or their regulators, arguing toward an epigenetic origin of the observed phenotype. Gene expression analysis, performed to assess the mechanism of HLA class II expression defects, revealed a significant downregulation of the major histocompatibility class II transactivator CIITA (MHC2TA) $(41,42)$, which in some patients was linked to hypermethylation of its promoters (42). We further showed that this feature is stably maintained upon transplantation and serial passages in immune-compromised mice, with levels of surface expression of HLA class II molecules in patient-derived xenografts (PDXs) perfectly mirroring those observed in the corresponding primary human samples (41).

Unexpectedly, however, when we infused donor-derived $\mathrm{T}$ cells to animals harboring the HLA class II-expressing diagnosis or the HLA class II-defective relapse, we observed that, although with a slower kinetics, the latter was also eventually recognized and eradicated. An in-depth study of this phenomenon showed that cross-recognition of murine antigens by the infused $\mathrm{T}$ cells led to the release of high levels of interferon- $\gamma$ (IFN$\gamma$ ) in the animal plasma and that this was followed by the recovery of HLA class II expression on leukemic cells (41). These findings were also confirmed by ex vivo experiments, in which post-transplantation leukemic blasts exposed to recombinant human IFN- $\gamma$ recovered HLA class II expression, and this in turn reconvened donor $\mathrm{T}$ cell-mediated recognition $(41,42)$. From a translational perspective, these results imply that a proinflammatory environment, driven by GvHD or recognition of antigens presented by HLA class I molecules, might actually revert this mechanism of relapse and re-establish a proficient antileukemic response.

Whereas, the description of deregulated HLA class II expression as a mechanism of AML post-transplantation relapse is extremely recent, there are a number of other malignancies in which alterations in HLA class II have been extensively investigated and that might provide precious hints on the molecular driver of the phenomenon in AML. For instance, there have been several reports of HLA class II downregulation in lymphoma cells as a consequence of deletions and point mutations of HLA class II genes and their regulators, including CIITA $(44,45)$. Moreover, in lymphomas, CIITA has been reported to be a recurrent fusion partner of the programmed death-ligands CD274/PD-L1 and CD273/PD-L2, leading to the downregulation of HLA class II genes and the upregulation of PD-L1 and PD-L2 (50). In addition, loss of HLA class II expression has also been linked to epigenetic silencing, as a consequence of mutations in epigenetic regulators (e.g., enhancer of zeste homolog 2, EZH2) or of hypermethylation or hypoacetylation of the promoters of HLA genes and/or CIITA $(42,44,45,51)$. Finally, Tarafdar et al. also proposed a cytokinemediated pathway of HLA class II silencing active in chronic myeloid leukemia: In this disease, tumor cells can produce antiinflammatory cytokines including IL-4 (52) and TGF- $\beta$ (53) that downregulate the expression of CIITA, rendering themselves less immunogenic and susceptible to $\mathrm{T}$ cell recognition $(52,54)$.

\section{Upregulation of T Cell Inhibitory Ligands}

While genomic and epigenetic alterations in HLA genes have all the final effect of turning tumor cells invisible to the donor-derived immune system, there is emerging evidence that leukemic cells can also hide in plain sight, using their encounter with $\mathrm{T}$ cells to transmit inhibitory signals that stun and impair antigen-specific responses. A number of reports have in fact shown that over the course of treatments and in particular after allo-HCT, hematologic malignancies increase their expression of molecules that inhibit $\mathrm{T}$ cell responses or drive their exhaustion, including members of the programmed death-ligand family $(41,55)$. In a recent study, retrospectively analyzing samples pairwise collected from AML patients at the time of diagnosis and at post-transplantation relapse, we showed increased expression of the inhibitory molecules PDL1, CD276/B7-H3, and CD155/PVRL2 in up to $40 \%$ of cases of relapse. PD-L1 overexpression on AML blasts impaired donor $\mathrm{T}$ cell functions ex vivo, and antileukemic responses could be partially restored upon treatment with anti-PD-L1 monoclonal antibody (41). It should be noted, however, that in most patients, the landscape of expression of inhibitory ligands at time of relapse was quite composite, with high interpatient variability, hinting at the fact that blocking a single interaction might yield limited clinical benefits and that efforts should rather be aimed at identifying and targeting a shared regulator of these molecules. The relative frequency of changes in $\mathrm{T}$ cell costimulation molecules remained superimposable when analyzed in different cohorts of patients receiving allo-HCT from donors with variable levels of HLA-compatibility (37), similarly to patients experiencing downregulation of HLA class II molecules at relapse and differently from patients with genomic loss of HLA-haplotype.

However, to date, little is known about the molecular drivers of this phenotype in the post-transplantation setting, and most of the currently available knowledge relates to PD-L1 and its regulation in other malignancies. Activation of aberrant janus 
kinase (JAK) signaling through 9p24.1 amplification has been shown to be a potent driver of PD-L1 upregulation in Hodgkin's lymphoma (56). Also, myeloproliferative neoplasms bearing the $J A K^{V 617 F}$ point mutation had the same effect on PD-L1 expression (57). With that said, loss-of-function mutations in the JAK/STAT pathway observed in several other tumor types (e.g., melanoma) have been proven to be associated with resistance to PD-1/PD-L1 blockade (58-60). Also, Myc-driven lymphomas display constitutive upregulation of inhibitory molecules: Myc oncogenic signaling has been shown in fact to increase the expression of PD-L1 and of the "don't eat me" signal CD47 in tumor cells, impairing interactions with $\mathrm{T}$ lymphocytes and dendritic cells (61). Beside oncogenes driving PD-L1 overexpression, several epigenetic mechanisms have also been reported. Expression of PD-L1 has been shown, for instance, to be inversely correlated with methylation of its promoter and robustly induced upon treatment of tumor cells with hypomethylating agents (62). Also, micro RNAs (miRNAs), have been implicated in the regulation of PD-L1 expression by binding to the PD-L1 mRNA and driving its degradation; in AML, for instance, the levels of miRNA-34a showed inverse correlation with PD-L1 expression (63). Another emerging layer of regulation of PD-L1 is represented by post-translational modifications-for instance, through glycosylation of the mature protein (64).

In addition to all the tumor-intrinsic mechanisms of PDL1 regulation mentioned in the previous paragraph, proinflammatory molecules (e.g., IFN- $\gamma$ ) secreted in the tumor microenvironment can also potently drive upregulation of PDL1 on tumor cells (65). This might be extremely relevant in the setting of leukemia post-transplantation relapses, since, as discussed in the previous section, induction of a proinflammatory microenvironment conversely represents the key to reverting epigenetic downregulation of HLA class II molecules. Indeed, when data regarding expression of HLA molecules and inhibitory ligands at relapse in our patient cohorts were plotted together, it appeared quite evident that these two modalities of relapse are largely non-overlapping (41) and should prospectively be discriminated one from the other to enact the most appropriate salvage treatments.

Noticeably, the phenotypic features of T cells circulating in patients at the time of relapse mirror the changes observed in leukemic cells, with significant upregulation of inhibitory receptors in the patients whose leukemias express the respective ligands $(41,66)$. Recent studies showed that expression of inhibitory receptors such as PD-1 on T lymphocytes can at least in part be prompted by the intense stimulation conveyed to the donor immune system upon transfer into an allogeneic environment (67), as suggested also by the observation of higher expression of inhibitory receptors on the $\mathrm{T}$ cells of patients who received haplo-HCTs (66). However, in-depth analysis of T cells from patients who did or did not experience relapse allowed for the identification of specific exhaustion features in $\mathrm{T}$ cells from relapsing patients, with co-expression of multiple inhibitory receptors not only in terminally differentiated effectors, but also in early-differentiated memory stem and central memory T cells $(66,68)$. The exhausted phenotype was particularly evident in the patients' bone marrow, where $\mathrm{T}$ cell-leukemia interactions are mainly expected to occur and associated with a skewed $\mathrm{T}$ cell receptor (TCR) repertoire (66). Importantly, backtracking the clinical follow-up of patients who eventually relapsed, it was possible to identify the $\mathrm{T}$ cell exhaustion signature even months before relapse $(41,66)$ and in patients who relapsed after sole chemotherapy (69), suggesting that, upon further validation, these features might be used as an indicator to guide pre-emptive therapeutic approaches.

\section{TUMOR-EXTRINSIC MECHANISMS OF RELAPSE}

Beside altering their features to increase aggressiveness and reduce immunogenicity, malignant cells can also accelerate disease progression by rewiring the microenvironment to their advantage, coopting the niche and the physiological mechanisms at the basis of immune tolerance. Mostly investigated in the context of solid tumors, interactions between cancer cells and the microenvironment are also starting to gain more attention in hematological diseases and gain an additional layer of complexity upon allo-HCT, when the niche becomes an admixture of pathological and non-pathological elements of both host and donor origin (Figure 2).

One of the best characterized modalities employed by hematological tumors to alter the immune microenvironment that surrounds them is switching from the production of proinflammatory cytokines to the release of immunosuppressive molecules, including IL-10 and TGF- $\beta$. For instance, it has been shown that during transformation, myeloid cells can reduce their production of granulocyte colony-stimulating factor (GCSF), IL-15, and IFN- $\gamma$. Defects in IFN- $\gamma$ production have been correlated to a specific polymorphism, which has been also linked to clinical risk parameters (e.g., prednisone response) in patients affected by B-lineage acute lymphocytic leukemia (ALL) (70). Strongly produced by normal myeloid progenitors, the physiological function of IL-15 is to expand and activate effector $\mathrm{T}$ and NK cells (71) and to promote the generation of memory stem $\mathrm{T}$ cell subset (72). Therefore, it is not difficult to understand why high levels of this cytokine in the tumor microenvironment are unfavorable for leukemic cells. In the post-transplantation setting, low plasma levels of IL-15 have been correlated to higher risk of relapse in patient affected by different hematological malignancies (73). One recently discovered mechanism at the basis of the reduced production of IL-15 by AML cells is the internal tandem duplication (ITD) of the FLT3 tyrosine kinase (FLT3-ITD) (74).

Even though in non-transplantation setting, the dysregulated effect of several metabolites has been shown to mediate immune suppression. The expression of indoleamine 2,3-dioxygenase1 (IDO1) by leukemia cells was for instance correlated with unfavorable prognosis in childhood AML (75). IDO1 is the first actor of an enzymatic cascade resulting in the inhibition of $\mathrm{T}$ cell function and the $\mathrm{T}$ regulatory cell reprogramming (76). Moreover, AML exhibits the ability to block T cell function through the amino acid arginase, which can also drive 


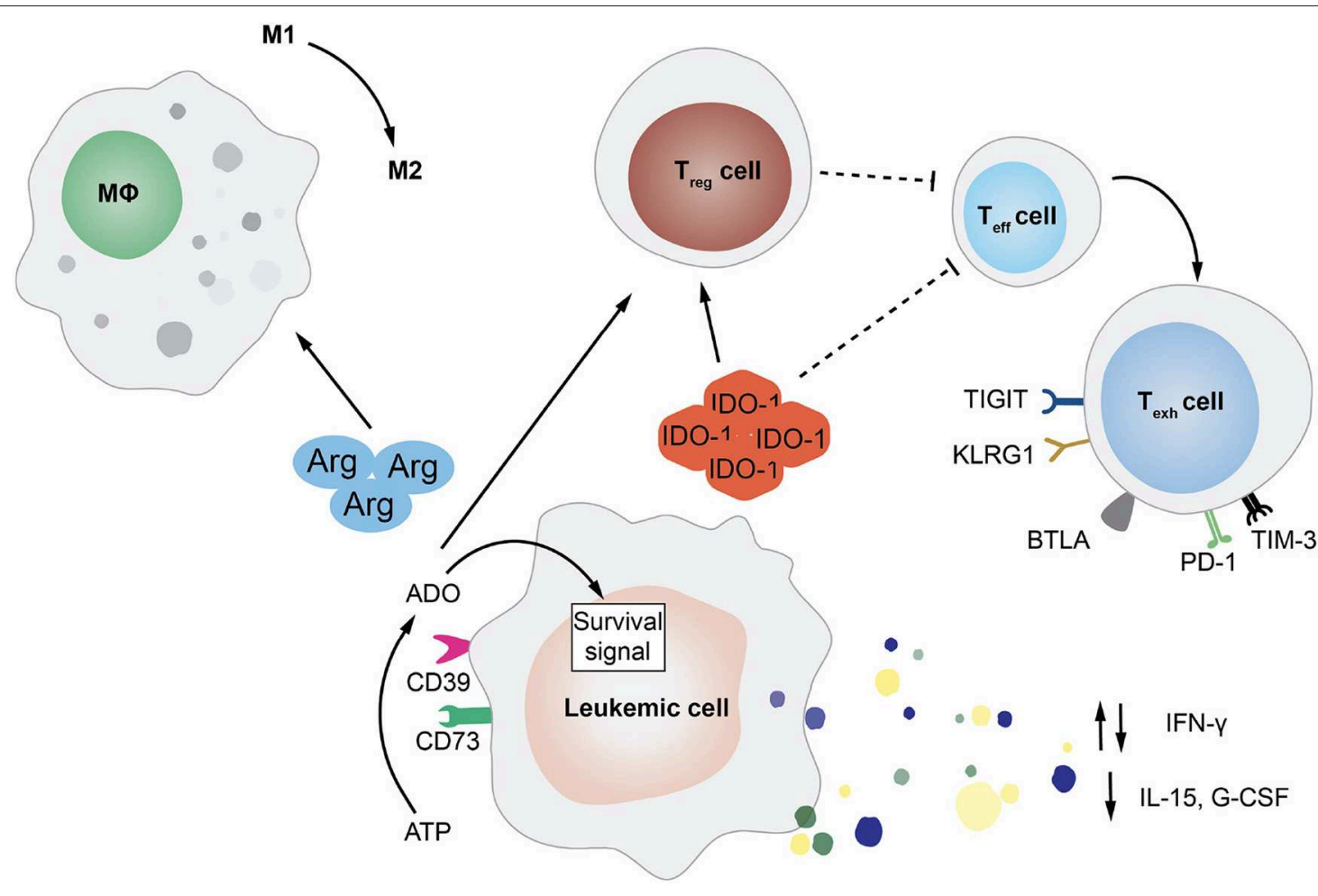

FIGURE 2 | Tumor-Extrinsic Mechanisms of Immune Evasion and Relapse. This cartoon summarizes several of the pathways exploited by leukemic cells in order to rewire the bone marrow microenvironment and evade immune recognition. In particular, featured in the figure are the deregulated release by AML blasts of cytokines, such as interferon- $\gamma$ (IFN- $\gamma$ ), interleukin-15 (IL-15), and granulocyte-colony stimulating factor (G-CSF); the expression of enzymes involved in aminoacid metabolism, such as arginase (Arg) and indoleamine 2,3-dioxygenase (IDO-1); and the upregulation of the ectonucleotidases CD73 and CD39 that leads to the increase in extracellular adenosine (ADO). All of these mediators can have an impact on the frequency and function of immune cell subsets, impairing $T$ and NK cell activity, driving effector T cells toward exhaustion, inducing the expansion of regulatory T cells (Treg), and promoting the phenotypic switch of macrophages from pro-inflammatory M1 to immuno-suppressive M2.

macrophages toward the suppressive M2-like phenotype (77). Other two enzymes that are gaining recent attention for their possible role in inducing leukemia immune escape are the ectonucleotidase CD73 (78) and the ectonucleoside triphosphate diphosphohydrolase-1 CD39 (79).

Recently, moreover, studies conducted in solid tumors highlighted a major role of tumor-induced metabolic remodeling in altering $\mathrm{T}$ cell state and function. Specifically, Vodnala et al. revealed that the elevated presence of extracellular potassium in the tumor microenvironment can promote a state of functional starvation in tumor-specific $\mathrm{T}$ cells. The starvation response results in induction of autophagy and in epigenetic reprogramming, impairing $\mathrm{T}$ cell differentiation and function (80).

\section{TRANSLATING RELAPSE BIOLOGY INTO RATIONALES FOR TREATMENT}

The ideal strategies to treat relapse after allo-HCT should exert both a direct anti-tumor activity and enhance the alloreactive GvL effect of allogeneic T cells, sparing the risks of inducing significant cytopenias, immunosuppression, or GvHD. Moreover, considering the numerous and complexly combined modalities of relapse that were summarized in previous section, it should be considered that, ideally only using combinatorial therapies, it might be possible to hit a target without exposing the flank to compensatory responses that ultimately select alternative mechanisms of escape.

Here, we summarize the most recent evidence about postHCT relapse treatment modalities, categorizing strategies that rely on cellular therapies or that aim at boosting or redirecting the pre-existent donor-derived immune system.

\section{Cellular Therapies \\ Donor Lymphocyte Infusions}

One of the simplest and most intuitive ways to induce a GvL response after allogeneic HCT is to administer donor-lymphocyte infusions (DLIs). The main advantage of this strategy is the induction of a polyclonal $\mathrm{T}$ cell response able to target multiple antigens on malignant cells, reducing the risks of escaping $\mathrm{T}$ cell recognition just by loss of a single antigen. The major drawback of DLIs is represented by the possibility of donor $\mathrm{T}$ cells recognizing and attacking non-hematopoietic tissues, with the risk of triggering GvHD, which can turn out to be a serious, and often fatal, complication. This hazard can be significantly reduced either by incorporating suicide genes in the infused cells, acting as a "safety switch" in case of unwanted reactions $(81,82)$, 
or by infusing specific $\mathrm{T}$ cell subsets endowed with lower intrinsic alloreactivity, such as memory $(83,84)$ or $\gamma \delta(85,86) \mathrm{T}$ cells.

As discussed in previous sections, when considering the therapeutic use of DLI for relapses after haplo-HCT, it is fundamental to rapidly determine if relapse is sustained by HLA loss immune-escape leukemia variants that represent a clear counter indication to DLI administration. In fact, the genomic loss of the unshared HLA haplotype in leukemia cells not only renders them invisible to the major HLA alloreactivity exerted by infused $\mathrm{T}$ cells, but it also does not impact their recognition of healthy tissues, leaving the risk of DLI-induced GvHD largely unaltered. For these reasons, upon documentation of HLA loss, other salvage options should be prioritized as treatment strategies $(17,39)$.

Outside of this specific context, a considerable body of literature exists on the use of DLI as therapy of relapse after haplo-HCT. The first study after unmanipulated haplo-HCT performed under ATG-based GvHD prophylaxis utilized a median dose of donor $\mathrm{T}$ cells of $0.6 \times 10^{8} \mathrm{CD}^{+} / \mathrm{Kg}$, reporting significant risks of both severe acute GvHD (aGvHD, 30\%) and chronic GvHD (cGvHD, 64\%) (87). More recently, a study testing DLI after post-transplant cyclophosphamide (PTCy)based GvHD prophylaxis yielded a 30\% complete remission (CR) rate, with a risk of developing grade III-IV aGvHD or $\mathrm{cGvHD}$ of 15 and $8 \%$, respectively. In this trial, a dose of $1 \times 10^{6} \mathrm{CD}^{+} / \mathrm{Kg}$ was considered a reasonable starting dose (88). Another study showed that escalating doses of DLI after PTCy-based haploHCT were accompanied by at least a $33 \% \mathrm{CR}$ rate, a $14 \%$ risk of grade II-III aGvHD, and no cases of grade III-IV aGvHD or cGvHD. In this study, the initial administered DLI dose was 1 $\times 10^{5} \mathrm{CD}^{+} / \mathrm{Kg}$, in case of molecular relapse, and higher (from $1 \times 10^{6}$ rising to $1 \times 10^{7} \mathrm{CD}^{+} / \mathrm{Kg}$ ), in case of hematological relapse (89).

Several studies also reported results from combinatorial administration of DLI and immunomodulating agents, with the aim of increasing the immunogenicity of tumor cells, rendering them more susceptible to DLI action. The diverse dose schedules and time points of infusions preclude a clear guideline, but most trials employed a starting dose of $1 \times 10^{5} \mathrm{CD}^{+} / \mathrm{Kg}$, eventually escalating in the absence of GvHD development (88, 90-98).

\section{Second Allogeneic Transplantation}

Second allogeneic transplantation (allo-HCT2) to treat relapse after the first allo-HCT has recently gained more popularity, thanks to the introduction of reduced-intensity conditioning and improvements of supportive therapies, which have significantly reduced toxicities after allo-HCT2, historically burdened by treatment-related mortality up to $40-50 \%(99,100)$. As in the case of DLI, when considering HCT2 for relapse after HLA-mismatched HCT, it is mandatory to discriminate whether relapse after the first transplant was classical or HLA loss. Especially in the second case, as mentioned above, selecting a second haploidentical donor with a different HLA haplotype provided some very promising preliminary results (40). Unfortunately, for all the studies on this subject, the inevitable selection bias of patients fit to receive a second conditioning and further transplantation must be taken into account, and clinical decisions must balance individual patient comorbidities and alternative therapeutic strategies.

\section{Adoptive Immunotherapy With Genetically Redirected Immune Cells}

Over the last few years, a number of landmark studies have demonstrated the feasibility and efficacy of using gene therapy to redirect immune cells in a non-HLA-restricted fashion against antigens of choice. The most striking example is provided by chimeric antigen receptor (CAR) T cells, which are capable of binding to the surface antigen of choice without the need for TCR-HLA interactions, thus representing a promising therapeutic option for patients relapsing with HLA loss or HLA downregulation. Moreover, CAR potent synthetic co-stimulatory domains may bypass the effect of the immune-suppressive signals expressed by tumor cells or microenvironment $(101,102)$.

CAR T cells targeting CD19 are, to date, the best studied and have demonstrated significant activity in chemotherapy refractory CLL, B-cell lymphomas and B-ALL in the autologous setting (103-108). There is also growing evidence of the efficacy of donor-origin CD19 CAR T cells in patients relapsing after allo-HCT $(102,108-111)$ or even haplo-HCT $(112,113)$. In this scenario, the infusion of allogeneic CAR $\mathrm{T}$ cells could carry the theoretical risk of GvHD; however, incidence of this fearsome complication in early trials was quite low, and an elegant study in mouse models showed that the CAR-driven and TCR-driven signal actually adds up, accelerating exhaustion and limiting alloreactions (101). Still, a number of studies are focusing on the development of improved strategies to further enhance CAR T efficacy and persistence without risking to induce GvHD, such as by transducing recipient-derived donor $\mathrm{T}$ cells (113), by using genome editing approaches to knock out the endogenous TCR $(101,114)$, or by modifying with the CAR different immune cells, less prone to induce $\operatorname{GvHD}(85,115,116)$.

\section{Redirecting or Boosting the Donor-Derived Immune System \\ Bispecific Antibodies}

Based on a principle similar to the one that guided the development of CAR T cells, bispecific antibodies can also enable redirection of immune cells toward malignant cells, forcing the formation of an immunological synapsis through the binding of an antigen expressed on effectors (such as CD3 on T cells or CD16 on NK cells), with one expressed by the tumor target (such as CD19 for lymphoid malignancies or CD33 for myeloid leukemias) $(117,118)$. This results in the release of cytotoxic granules in close proximity to target cells, with the ultimate step of apoptosis induction and elimination, also fueled by inflammatory cytokines production and antigen spreading mechanisms (119). This strategy could be another useful way to circumvent HLA-restriction of TCR, with the potential added value of being readily available off the shelf and taking advantage of cells that are already circulating in the patient and tolerized against his healthy tissues. However, other immune-evasion mechanisms (related to the induction of inhibitory checkpoint molecules and the production of immunosuppressive cytokines 
or metabolites), have been shown to rapidly emerge upon treatment with bispecifics, suggesting that full exploitation of the anti-tumoral activity of these promising molecules could pass by enhancing costimulatory pathways or blocking immune checkpoints (120-125).

\section{Epigenetic Therapies}

The two commercially available hypomethylating agents (HMAs), azacytidine (Aza) and decitabine (DAC), are frequently used for post-HCT relapse treatment in AML or myelodysplastic syndromes (MDS). HMAs indirectly inhibit DNA methyltransferases significantly altering DNA methylation patterns with consequent induction of cell cycle arrest, DNA damage accumulation, apoptosis, and differentiation (126-132). More recently, immune-related effects of hypomethylating agents have also been described. In particular, Aza stimulates antitumor immunity inducing the upregulation on leukemic cells of leukemia-associated and minor-histocompatibility antigens, including PRAME, MAGE-A, NY-ESO1, and HA-1 $(129,130,133-136)$. Aza can also lead to increased HLA class-I and II expression and modulate tumor-immunogenicity through the upregulation on leukemic cell surface of costimulatory molecules, such as CD80, CD86, ULBP, and MIC-A (137). Among the reported effects, HMAs can induce the expression of important players involved in anti-viral responses, including IFN- $\gamma$ and cytokines. Interestingly, Aza can also promote upregulation of endogenous retroviral elements on tumor cells, inducing a "viral mimicry" response that ultimately results in the induction of anti-tumor immunity (138-140). However, Aza can also act as a double-edged sword, since it can upregulate PD-1, PD-L1/L2, and CTLA-4 inhibitory pathways and induce the expansion of regulatory $\mathrm{T}$ cells (131), potentially hampering the intensity and duration of cytotoxic $\mathrm{T}$ cell responses and facilitating the tolerization and exhaustion of tumor-specific $\mathrm{T}$ cells $(141,142)$.

Due to their reported immune-related effects, HMAs have been frequently employed in combination with DLI. To date, we have data on more than 600 patients undergoing salvage regimens including Aza and DLI, reporting very variable results in terms of clinical outcome (143-148). Because of the heterogeneous results obtained so far and lack of consent on treatment schedules, two retrospective surveys have analyzed the correlates of efficacy of Aza+DLI combinations in more homogeneous cohorts, one facilitated by the German Cooperative Transplant Study Group (145) and the other by the EBMT (146). These studies reported that patients that benefitted the most from Aza+DLI combinatorial approach were those who presented low disease burden at the time of relapse (molecular relapse or $<20 \%$ blasts in bone marrow) and those with a longer interval from allo-HCT to relapse. These variables can be adopted to predict treatment response through a score assignment (AZA relapse prognostic score: ARPS), even if an independent validation cohort is still lacking (146).

Histone acetylation is another epigenetic mechanism of immune regulation, balanced between the activity of histone acetyl-transferases (HATs) and histone deacetylases (HDACs). HDAC inhibitors, such as vorinostat and panobinostat, have been associated with the upregulation of major-histocompatibility and co-stimulatory molecules on AML cell surface through the induction of an open and readable structure of chromatin (149, 150). To date, two prospective phase I/II trials of post-HCT therapy with panobinostat for AML/MDS patients, alone or in combination with DAC and DLI, have been reported $(151,152)$.

\section{Immune Checkpoint Blockade}

Immune checkpoint inhibition through the administration of monoclonal antibodies that target the PD-1/PD-L1 and CTLA4/B7 axes is emerging as an attractive strategy to enhance alloreactive $\mathrm{T}$ cell function and rewire the immunosuppressive milieu in which disease relapse often occurs (153-155). Clinical trials exploring the efficacy of immune checkpoint inhibitors after allo-HCT have shown some promise using the antiCTLA4 antibody ipilimumab $(156,157)$ and more modest results using PD-1 inhibitors in diseases other than Hodgkin's lymphoma (158-161). Moreover, post-transplantation treatment with checkpoint inhibitors appears to be associated to a significant risk of severe and treatment-refractory GvHD and immune-related events (162).

However, as the balance of stimulatory and inhibitory signals determines the magnitude of immune responses against tumor cells, combining HMAs and immune-checkpoint blockade therapies may represent an interesting approach to release the "break" signal received by tumor-reactive immune cells (163165). A phase II trial exploring the combination of the antiPD1 monoclonal antibody Nivolumab and Aza in relapsed AML reported an overall response rate of 33\% (166), and several ongoing trials are assessing the efficacy of HMAs and immune checkpoint inhibitor combinations, some of them recruiting also post-transplantation relapsed patients (NCT02890329, NCT02845297, NCT02996474, and NCT02397720).

\section{Cytokine Therapies}

The use of exogenous cytokines to boost or restore $\mathrm{T}$ celland NK cell-impaired effector functions have been object of intense investigation in cancer therapy and especially in the field of hematological malignancies. Interleukin 2 (IL2), IFN$\alpha$, and IL-15 are the best studied. IL-2 has been shown to stimulate the anti-tumor effect of lymphocytes, polarizing helper $\mathrm{T}$ cell responses toward type 1 and exerting both immune-enhancing and immune-suppressive activities (167169). However, application of IL-2 monotherapy against AML has yielded very limited clinical benefit, both for the induction of regulatory $\mathrm{T}$ cells that impaired antileukemic activity and for the rapid drop in effector functions due to $\mathrm{T}$ cells terminal differentiation and exhaustion (170-173). IFN- $\alpha$, however, exerts pleiotropic functions, since it has a direct antileukemic effect and also possesses immune-stimulatory properties, leading to dendritic cells stimulation, enhancement of NK-cell cytotoxicity, and sensitization of $\mathrm{T}$ cells to other inflammatory cytokines, such as IL-2 (174-177). Despite these theoretical premises, IFN- $\alpha$ failed to demonstrate significant activity as single agent in posttransplantation relapse (178-181). As previously described, IL-15 is a potent immunostimulatory cytokine, that potentiates both $\mathrm{T}$ and NK cell immune responses, promoting the generation and 
maintenance of high-avidity and long-lived $\mathrm{CD}^{+}$memory $\mathrm{T}$ cells. IL-15 also prevents activation-induced T cell death and does not induce the expansion of immunosuppressive regulatory $\mathrm{T}$ cells $(72,182-186)$. A phase I trial testing the IL-15 super-agonist complex ALT-803 in patients relapsing after allo-HCT showed a very promising response rate (19\% of evaluable patients), correlated to the expansion of both NK and T cells (187). Recently, novel approaches to transfer high concentration of cytokines to the tumor site and reduce their systemic effects are emerging, including gene therapy "Trojan Horse" strategies (188) and the use of lipid nanoparticles to convey to the tumor site mRNAs encoding cytokines (189).

\section{Immune-Related Effects of Targeted Therapies}

The growing armamentarium of targeted therapies is providing new evidence that, beside their direct effects, some of them can also promote antitumor immunity. A recent work testing the effect of the tyrosine-kinase inhibitor sorafenib in a mouse model of leukemia showed that the treatment increased the production of IL-15 by leukemic cells bearing FLT3-ITD. This resulted in enhanced $\mathrm{CD}^{+} \mathrm{T}$ cell effector function (via their increased metabolic capacity) and leukemia eradication. Mechanistically, sorafenib induced transcription of IL-15, acting by inhibition of the transcription factor ATF435 that in turn suppresses the IL-15 activator interferon regulatory factor 7 (IRF7) (74).

Another example of tyrosine-kinase inhibitor exerting "offtarget" immune mechanisms is represented by imatinib, which is indicated in Philadelphia-positive $(\mathrm{Ph}+)$ leukemias, namely chronic myeloid leukemia (CML) and $\mathrm{Ph}+$ acute lymphoblastic leukemia (ALL). Allogeneic HCT remains the only curative option for $\mathrm{Ph}+\mathrm{ALL}$ and advanced-phase CML, and there is general consensus about imatinib administration following HCT $(190,191)$. In addition to targeting Bcr/Abl1 and KIT oncogene products, imatinib modulates the proliferation, polarization, and functionality of different subsets of myeloid and lymphoid cells (192-195). This modulation can exert either inhibitory or stimulating immune effects. Among the inhibitory effects are the inhibition of dendritic cells expansion, resulting in less efficient priming of cytotoxic $\mathrm{T}$ cells (196-199), the polarization toward a M2-like anti-inflammatory phenotype of tumor-associated macrophages (200, 201), the reduction of effector-cytokine production by $\mathrm{CD}^{+} \mathrm{T}$ cells in response to TCR-signaling $(202,203)$, and the reduction of IgMproducing memory B-cell frequency (204-206). On the other hand, imatinib also has stimulating effects such as decreased expression of 2,3-IDO and consequent apoptosis in regulatory $\mathrm{T}$ cells (207, 208); reduction of myeloid-derived suppressor cells, thus restoring a $\mathrm{T}$ cell cytotoxic response (209-211); reduced secretion of VEGF with subsequent antiangiogenic effect $(212,213)$; polarization toward a higher Th1/Th2 ratio (214-216); and preferential expression of activating NK receptors (217).

\section{CONCLUSIONS AND PERSPECTIVES}

The landscape of allo-HCT, and haplo-HCT in particular, is rapidly changing, with multiple platforms able to achieve remarkable long-term outcome results. The reduced risk of treatment-related toxicities and mortality has also opened the possibility to implement innovative pharmacological or cellular therapies in the post-transplantation follow-up, transforming the perception of allo-HCT from that of a final consolidation therapy to a "platform" to build on. In this new scenario, it will be of utmost relevance to also associate to the analysis of clinical endpoints a detailed study on how changing the recipe of allo-HCT influences its immunobiology. For instance, understanding the relative contribution of each immune cell subset transferred as part of the graft in the induction of GvHD and protection against relapse will be fundamental to guide further improvements in "tailoring" graft composition and posttransplantation cell therapies, as convincingly suggested by a number of recent studies (218-220). It is now evident that the success or failure of transplantation is linked to our ability to take full advantage of the many features endowed in the immune system and to combine them with targeted therapies to hit as many tumor targets as possible, reducing the chances of selection of escape variants. Generation of new quantitative systems to map tumor immune targets, characterization of the tumor immune microenvironment by multi-omics singlecell technologies, and generation of more refined humanized mouse model to mirror allo-HCT all appear to be promising avenues in advancing knowledge on allo-HCT immunobiology and, ultimately, in generating new rationales to further improve clinical outcome.

\section{AUTHOR CONTRIBUTIONS}

$\mathrm{PR}, \mathrm{VG}$, and FL reviewed available literature and drafted the paper. FC and LV provided critical discussion and revised the manuscript draft.

\section{FUNDING}

LV would like to acknowledge support from the Italian Ministry of Health (RF-2011-02351998, RF-2011-02348034, and TRANSCAN HLALOSS), the Associazione Italiana per la Ricerca sul Cancro (Start-Up Grant \#14162 and IG \#22197), and the DKMS Mechtild Harf Foundation (DKMS Mechtild Harf Research Grant 2015).

\section{ACKNOWLEDGMENTS}

The authors would like to thank all members of the Unit of Immunogenetics, Leukemia Genomics, and Immunobiology, IRCCS San Raffaele Scientific Institute, Milano for critical reading and discussion on the text. 


\section{REFERENCES}

1. Kanakry CG, Fuchs EJ, Luznik L. Modern approaches to HLA-haploidentical blood or marrow transplantation. Nat Rev Clin Oncol. (2016) 13:10-24. doi: $10.1038 /$ nrclinonc. 2015.128

2. Patriarca F, Luznik L, Medeot M, Zecca M, Bacigalupo A, Di Bartolomeo $\mathrm{P}$, et al. Experts' considerations on HLA-haploidentical stem cell transplantation. Eur J Haematol. (2014) 93:187-97. doi: 10.1111/ejh.12322

3. Aversa F, Pierini A, Ruggeri L, Martelli MF, Velardi A. The evolution of T cell depleted haploidentical transplantation. Front Immunol. (2019) 10:2769. doi: 10.3389/fimmu.2019.02769

4. Martelli MF, Di Ianni M, Ruggeri L, Falzetti F, Carotti A, Terenzi A, et al. HLA-haploidentical transplantation with regulatory and conventional T-cell adoptive immunotherapy prevents acute leukemia relapse. Blood. (2014) 124:638-44. doi: 10.1182/blood-2014-03-564401

5. Mancusi A, Piccinelli S, Velardi A, Pierini A. CD4+FOXP3+ Regulatory T cell therapies in HLA haploidentical hematopoietic transplantation. Front Immunol. (2019) 10:2901. doi: 10.3389/fimmu.2019.02901

6. Ciceri F, Bonini C, Stanghellini MTL, Bondanza A, Traversari C, Salomoni $\mathrm{M}$, et al. Infusion of suicide-gene-engineered donor lymphocytes after family haploidentical haemopoietic stem-cell transplantation for leukaemia (the TK007 trial): a non-randomised phase I-II study. Lancet Oncol. (2009) 10:489-500. doi: 10.1016/S1470-2045(09)70074-9

7. Lucarelli B, Bertaina A, Merli P, Quintarelli C, Pende D, Falco M, et al. T-cell depleted HLA-haploidentical allogeneic hematopoietic stem cell transplantation (haplo-HSCT) followed by donor lymphocyte infusion with $\mathrm{T}$ cells transduced with the inducible caspase 9 (iC9) suicide gene in children with hematological malignancies. Blood. (2016) 128:4683. doi: 10.1182/blood.V128.22.4683.4683

8. Zhang P, Tey S-K. Adoptive T cell therapy following haploidentical hematopoietic stem cell transplantation. Front Immunol. (2019) 10:1854. doi: 10.3389/fimmu.2019.01854

9. Huang X-J, Liu D-H, Liu K-Y, Xu L-P, Chen H, Han W, et al. Haploidentical hematopoietic stem cell transplantation without in vitro T-cell depletion for the treatment of hematological malignancies. Bone Marrow Transplant. (2006) 38:291-7. doi: 10.1038/sj.bmt.1705445

10. Luznik L, O’Donnell PV, Symons HJ, Chen AR, Leffell MS, Zahurak $\mathrm{M}, \mathrm{G}$ et al. HLA-haploidentical bone marrow transplantation for hematologic malignancies using nonmyeloablative conditioning and highdose, posttransplantation cyclophosphamide. Biol Blood Marrow Transplant. (2008) 14:641-50. doi: 10.1016/j.bbmt.2008.03.005

11. Passweg JR, Baldomero H, Basak GW, Chabannon C, Corbacioglu S, Duarte R, et al. The EBMT activity survey report 2017: a focus on allogeneic HCT for nonmalignant indications and on the use of non-HCT cell therapies. Bone Marrow Transplant. (2019) 54:1575-85. doi: 10.1038/s41409-01 9-0465-9

12. D'Souza A, Fretham C. Current Uses and Outcomes of Hematopoietic Cell Transplantation (HCT): CIBMTR Summary Slides, 2019. Available online at: https://www.cibmtr.org (accessed February 19, 2020)

13. Horowitz MM, Gale RP, Sondel PM, Goldman JM, Kersey J, Kolb HJ, et al. Graft-vs.-leukemia reactions after bone marrow transplantation. Blood. (1990) 75:555-62. doi: 10.1182/blood.V75.3.555.555

14. Garrido F, Perea F, Bernal M, Sánchez-Palencia A, Aptsiauri N, RuizCabello $\mathrm{F}$. The escape of cancer from $\mathrm{T}$ cell-mediated immune surveillance: HLA class I loss and tumor tissue architecture. Vaccines. (2017) 5:7. doi: 10.3390/vaccines5010007

15. Masuda K, Hiraki A, Fujii N, Watanabe T, Tanaka M, Matsue K, et al. Loss or down-regulation of HLA class I expression at the allelic level in freshly isolated leukemic blasts. Cancer Sci. (2007) 98:102-8. doi: 10.1111/j.1349-7006.2006.00356.x

16. Brouwer RE, van der Heiden P, Schreuder GMT, Mulder A, Datema G, Anholts JDH, et al. Loss or downregulation of HLA class I expression at the allelic level in acute leukemia is infrequent but functionally relevant, and can be restored by interferon. Hum Immunol. (2002) 63:200-10. doi: 10.1016/S0198-8859(01)00381-0

17. Vago L, Perna SK, Zanussi M, Mazzi B, Barlassina C, Stanghellini MTL, et al. Loss of mismatched HLA in leukemia after stem-cell transplantation. $N$ Engl JMed. (2009) 361:478-88. doi: 10.1056/NEJMoa0811036
18. Mazzi B, Clerici TD, Zanussi M, Lupo Stanghellini MT, Vago L, Sironi E, et al. Genomic typing for patient-specific human leukocyte antigen-alleles is an efficient tool for relapse detection of high-risk hematopoietic malignancies after stem cell transplantation from alternative donors. Leukemia. (2008) 22:2119-22. doi: 10.1038/leu.2008.98

19. Makishima H, Maciejewski JP. Pathogenesis and consequences of uniparental disomy in cancer. Clin Cancer Res. (2011) 17:3913-23. doi: 10.1158/1078-0432.CCR-10-2900

20. O’Keefe C, McDevitt MA, Maciejewski JP. Copy neutral loss of heterozygosity: a novel chromosomal lesion in myeloid malignancies. Blood. (2010) 115:2731-9. doi: 10.1182/blood-2009-10-201848

21. Tuna M, Knuutila S, Mills GB. Uniparental disomy in cancer. Trends Mol Med. (2009) 15:120-8. doi: 10.1016/j.molmed.2009.01.005

22. Villalobos IB, Takahashi Y, Akatsuka Y, Muramatsu H, Nishio $\mathrm{N}$, Hama A, et al. Relapse of leukemia with loss of mismatched HLA resulting from uniparental disomy after haploidentical hematopoietic stem cell transplantation. Blood. (2010) 115:3158-61. doi: 10.1182/blood-2009-11-254284

23. Kärre K, Ljunggren HG, Piontek G, Kiessling R. Selective rejection of H-2deficient lymphoma variants suggests alternative immune defence strategy. Nature. (1986) 319:675-8. doi: 10.1038/319675a0

24. Barrett J, Blazar BR. Genetic trickery - escape of leukemia from immune attack. N Engl J Med. (2009) 361:524-5. doi: 10.1056/NEJMe0903177

25. Gupta M, Raghavan M, Gale RE, Chelala C, Allen C, Molloy G, et al. Novel regions of acquired uniparental disomy discovered in acute myeloid leukemia. Genes Chromoso Cancer. (2008) 47:729-39. doi: 10.1002/gcc.20573

26. Dubois V, Sloan-Béna F, Cesbron A, Hepkema BG, Gagne K, Gimelli S, et al. Pretransplant HLA mistyping in diagnostic samples of acute myeloid leukemia patients due to acquired uniparental disomy. Leukemia. (2012) 26:2079-85. doi: 10.1038/leu.2012.68

27. Pereira S, Vayntrub T, Hiraki DD, Cherry AM, Arai S, Dvorak CC, et al. Short tandem repeat and human leukocyte antigen mutations or losses confound engraftment and typing analysis in hematopoietic stem cell transplants. Hum Immunol. (2011) 72:503-9. doi: 10.1016/j.humimm.2011.03.003

28. Crucitti L, Crocchiolo R, Toffalori C, Mazzi B, Greco R, Signori A, et al. Incidence, risk factors and clinical outcome of leukemia relapses with loss of the mismatched HLA after partially incompatible hematopoietic stem cell transplantation. Leukemia. (2015) 29:1143-52. doi: 10.1038/leu.20 14.314

29. McCurdy SR, Iglehart BS, Batista DA, Gocke CD, Ning Y, Knaus HA, et al. Loss of the mismatched human leukocyte antigen haplotype in two acute myelogenous leukemia relapses after haploidentical bone marrow transplantation with post-transplantation cyclophosphamide. Leukemia. (2016) 30:2102-6. doi: 10.1038/leu.2016.144

30. Grosso D, Johnson E, Colombe B, Alpdogan O, Carabasi M, Filicko-O'Hara J, et al. Acquired uniparental disomy in chromosome $6 \mathrm{p}$ as a feature of relapse after T-cell replete haploidentical hematopoietic stem cell transplantation using cyclophosphamide tolerization. Bone Marrow Transplant. (2017) 52:615-9. doi: 10.1038/bmt.2016.324

31. Peccatori J, Forcina A, Clerici D, Crocchiolo R, Vago L, Stanghellini MTL, et al. Sirolimus-based graft-vs.-host disease prophylaxis promotes the in vivo expansion of regulatory $\mathrm{T}$ cells and permits peripheral blood stem cell transplantation from haploidentical donors. Leukemia. (2015) 29:396-405. doi: 10.1038/leu.2014.180

32. Cieri N, Greco R, Crucitti L, Morelli M, Giglio F, Levati G, et al. Posttransplantation cyclophosphamide and sirolimus after haploidentical hematopoietic stem cell transplantation using a treosulfan-based myeloablative conditioning and peripheral blood stem cells. Biol Blood Marrow Transplant. (2015) 21:1506-14. doi: 10.1016/j.bbmt.2015. 04.025

33. Toffalori C, Cavattoni I, Deola S, Mastaglio S, Giglio F, Mazzi B, et al. Genomic loss of patient-specific HLA in acute myeloid leukemia relapse after well-matched unrelated donor HSCT. Blood. (2012) 119:4813-5. doi: 10.1182/blood-2012-02-411686

34. Waterhouse M, Pfeifer D, Pantic M, Emmerich F, Bertz H, Finke J. Genomewide profiling in AML patients relapsing after allogeneic hematopoietic cell transplantation. Biol Blood Marrow Transplant. (2011) 17:1450-9.e1. doi: 10.1016/j.bbmt.2011.07.012 
35. Hamdi A, Cao K, Poon LM, Aung F, Kornblau S, Fernandez Vina MA, et al. Are changes in HLA Ags responsible for leukemia relapse after HLAmatched allogeneic hematopoietic SCT? Bone Marrow Transplant. (2015) 50:411-3. doi: 10.1038/bmt.2014.285

36. Jan M, Leventhal MJ, Morgan EA, Wengrod JC, Nag A, Drinan SD, et al. Recurrent genetic HLA loss in AML relapsed after matched unrelated allogeneic hematopoietic cell transplantation. Blood Adv. (2019) 3:2199-204. doi: 10.1182/bloodadvances.2019000445

37. Tsirigotis P, Byrne M, Schmid C, Baron F, Ciceri F, Esteve J, et al. Relapse of AML after hematopoietic stem cell transplantation: methods of monitoring and preventive strategies. a review from the ALWP of the EBMT. Bone Marrow Transplant. (2016) 51:1431-38. doi: 10.1038/bmt.2016.167

38. Ahci M, Toffalori C, Bouwmans E, Crivello P, Brambati C, Pultrone C, et al. A new tool for rapid and reliable diagnosis of HLA loss relapses after HSCT. Blood. (2017) 130:1270-3. doi: 10.1182/blood-2017-05-7 84306

39. Vago L, Ciceri F. Choosing the alternative. Biol Blood Marrow Transplant. (2017) 23:1813-4. doi: 10.1016/j.bbmt.2017.09.009

40. Imus PH, Blackford AL, Bettinotti M, Iglehart B, Dietrich A, Tucker N, et al. Major histocompatibility mismatch and donor choice for second allogeneic bone marrow transplantation. Biol Blood Marrow Transplant. (2017) 23:1887-94. doi: 10.1016/j.bbmt.2017.07.014

41. Toffalori C, Zito L, Gambacorta V, Riba M, Oliveira G, Bucci G, et al. Immune signature drives leukemia escape and relapse after hematopoietic cell transplantation. Nat Med. (2019) 25:603-11. doi: 10.1038/s41591-019-0400-z

42. Christopher MJ, Petti AA, Rettig MP, Miller CA, Chendamarai E, Duncavage EJ, et al. Immune escape of relapsed AML cells after allogeneic transplantation. N Engl J Med. (2018) 379:2330-41. doi: 10.1056/NEJMoa1808777

43. Stevanović S, van Schie MLJ, Griffioen M, Falkenburg JH. HLA-class II disparity is necessary for effective $\mathrm{T}$ cell mediated graft-vs.-leukemia effects in NOD/scid mice engrafted with human acute lymphoblastic leukemia. Leukemia. (2013) 27:985-7. doi: 10.1038/leu.2012.270

44. Ennishi D, Takata K, Béguelin W, Duns G, Mottok A, Farinha P, et al. Molecular and genetic characterization of MHC deficiency identifies EZH2 as therapeutic target for enhancing immune recognition. Cancer Discov. (2019) 9:546-63. doi: 10.1158/2159-8290.CD-18-1090

45. Rimsza LM, Roberts RA, Miller TP, Unger JM, LeBlanc M, Braziel RM, et al. Loss of MHC class II gene and protein expression in diffuse large Bcell lymphoma is related to decreased tumor immunosurveillance and poor patient survival regardless of other prognostic factors: a follow-up study from the leukemia and lymphoma molecular profiling project. Blood. (2004) 103:4251-8. doi: 10.1182/blood-2003-07-2365

46. Løvig T, Andersen SN, Thorstensen L, Diep CB, Meling GI, Lothe RA, et al. Strong HLA-DR expression in microsatellite stable carcinomas of the large bowel is associated with good prognosis. Br J Cancer. (2002) 87:756-62. doi: 10.1038/sj.bjc.6600507

47. Roemer MGM, Redd RA, Cader FZ, Pak CJ, Abdelrahman S, Ouyang J, et al. Major histocompatibility complex class II and programmed death ligand 1 Expression predict outcome after programmed death 1 blockade in classic hodgkin lymphoma. J Clin Oncol. (2018) 36:942-50. doi: 10.1200/JCO.2017.77.3994

48. Lansford JL, Dharmasiri U, Chai S, Hunsucker SA, Bortone DS, Keating $\mathrm{JE}$, et al. Computational modeling and confirmation of leukemiaassociated minor histocompatibility antigens. Blood Adv. (2018) 2:2052-62. doi: 10.1182/bloodadvances.2018022475

49. Salman A, Koparde V, Hall CE, Jameson-Lee M, Roberts C, Serrano $\mathrm{M}$, et al. Determining the quantitative principles of $\mathrm{T}$ cell response to antigenic disparity in stem cell transplantation. Front Immunol. (2018) 9:2284. doi: 10.3389/fimmu.2018.02284

50. Steidl C, Shah SP, Woolcock BW, Rui L, Kawahara M, Farinha P, et al. MHC class II transactivator CIITA is a recurrent gene fusion partner in lymphoid cancers. Nature. (2011) 471:377-81. doi: 10.1038/nature09754

51. Cycon KA, Mulvaney K, Rimsza LM, Persky D, Murphy SP. Histone deacetylase inhibitors activate CIITA and MHC class II antigen expression in diffuse large B-cell lymphoma. Immunology. (2013) 140:259-72. doi: $10.1111 /$ imm. 12136
52. Tarafdar A, Hopcroft LEM, Gallipoli P, Pellicano F, Cassels J, Hair A, et al. CML cells actively evade host immune surveillance through cytokinemediated downregulation of MHC-II expression. Blood. (2017) 129:199-208. doi: 10.1182/blood-2016-09-742049

53. Naka K, Hoshii T, Muraguchi T, Tadokoro Y, Ooshio T, Kondo Y, et al. TGF-beta-FOXO signalling maintains leukaemia-initiating cells in chronic myeloid leukaemia. Nature. (2010) 463:676-80. doi: 10.1038/nature08734

54. Lee YJ, Han Y, Lu HT, Nguyen V, Qin H, Howe PH, et al. TGF-beta suppresses IFN-gamma induction of class II MHC gene expression by inhibiting class II transactivator messenger RNA expression. J Immunol. (1997) 158:2065-75.

55. Norde WJ, Maas F, Hobo W, Korman A, Quigley M, Kester MGD, et al. PD1/PD-L1 interactions contribute to functional T-cell impairment in patients who relapse with cancer after allogeneic stem cell transplantation. Cancer Res. (2011) 71:5111-22. doi: 10.1158/0008-5472.CAN-11-0108

56. Green MR, Monti S, Rodig SJ, Juszczynski P, Currie T, O’Donnell E, et al. Integrative analysis reveals selective 9p24.1 amplification, increased PD-1 ligand expression, and further induction via JAK2 in nodular sclerosing Hodgkin lymphoma and primary mediastinal large B-cell lymphoma. Blood. (2010) 116:3268-77. doi: 10.1182/blood-2010-05-282780

57. Prestipino A, Emhardt AJ, Aumann K, O’Sullivan D, Gorantla SP, Duquesne $\mathrm{S}$, et al. Oncogenic JAK2V617F causes PD-L1 expression, mediating immune escape in myeloproliferative neoplasms. Sci Transl Med. (2018) 10:eaam7729. doi: 10.1126/scitranslmed.aam7729

58. Shin DS, Zaretsky JM, Escuin-Ordinas H, Garcia-Diaz A, HuLieskovan S, Kalbasi A, et al. Primary resistance to PD-1 blockade mediated by JAK1/2 mutations. Cancer Discov. (2017) 7:188-201. doi: 10.1158/2159-8290.CD-16-1223

59. Zaretsky JM, Garcia-Diaz A, Shin DS, Escuin-Ordinas H, Hugo W, $\mathrm{Hu}-$ Lieskovan S, et al. Mutations associated with acquired resistance to PD-1 blockade in melanoma. N Engl J Med. (2016) 375:819-29. doi: 10.1056/NEJMoa1604958

60. Sucker A, Zhao F, Pieper N, Heeke C, Maltaner R, Stadtler N, et al. Acquired IFN $\gamma$ resistance impairs anti-tumor immunity and gives rise to T-cell-resistant melanoma lesions. Nat Commun. (2017) 8:15440. doi: 10.1038/ncomms15440

61. Casey SC, Tong L, Li Y, Do R, Walz S, Fitzgerald KN, et al. MYC regulates the antitumor immune response through CD47 and PD-L1. Science. (2016) 352:227-31. doi: 10.1126/science.aac9935

62. Wrangle J, Wang W, Koch A, Easwaran H, Mohammad HP, Vendetti F, et al. Alterations of immune response of non-small cell lung cancer with azacytidine. Oncotarget. (2013) 4:2067-79. doi: 10.18632/oncotarget.1542

63. Wang X, Li J, Dong K, Lin F, Long M, Ouyang Y, et al. Tumor suppressor miR-34a targets PD-L1 and functions as a potential immunotherapeutic target in acute myeloid leukemia. Cell Signal. (2015) 27:443-52. doi: 10.1016/j.cellsig.2014.12.003

64. Li C-W, Lim S-O, Xia W, Lee H-H, Chan L-C, Kuo C-W, et al. Glycosylation and stabilization of programmed death ligand-1 suppresses T-cell activity. Nat Commun. (2016) 7:12632. doi: 10.1038/ncomms12632

65. Liu J, Hamrouni A, Wolowiec D, Coiteux V, Kuliczkowski K, Hetuin D, et al. Plasma cells from multiple myeloma patients express B7-H1 (PD-L1) and increase expression after stimulation with IFN- $\gamma$ and TLR ligands via a MyD88-, TRAF6-, and MEK-dependent pathway. Blood. (2007) 110:296304. doi: 10.1182/blood-2006-10-051482

66. Noviello M, Manfredi F, Ruggiero E, Perini T, Oliveira G, Cortesi F, et al. Bone marrow central memory and memory stem T-cell exhaustion in AML patients relapsing after HSCT. Nat Commun. (2019) 10:1065. doi: 10.1038/s41467-019-08871-1

67. Simonetta F, Pradier A, Bosshard C, Masouridi-Levrat S, Dantin C, Koutsi A, et al. Dynamics of expression of programmed cell death protein-1 (PD1) on $T$ cells after allogeneic hematopoietic stem cell transplantation. Front Immunol. (2019) 10:1034. doi: 10.3389/fimmu.2019.01034

68. Hutten TJA, Norde WJ, Woestenenk R, Wang RC, Maas F, Kester $\mathrm{M}$, et al. Increased coexpression of PD-1, TIGIT, and KLRG-1 on tumor-reactive CD8 $+\mathrm{T}$ Cells during relapse after allogeneic stem cell transplantation. Biol Blood Marrow Transplant. (2018) 24:666-77. doi: 10.1016/j.bbmt.2017.11.027

69. Knaus HA, Berglund S, Hackl H, Blackford AL, Zeidner JF, Montiel-Esparza $\mathrm{R}$, et al. Signatures of CD8+ T cell dysfunction in AML patients and their 
reversibility with response to chemotherapy. JCI Insight. (2018) 3:120974. doi: 10.1172/jci.insight.120974

70. Cloppenborg T, Stanulla M, Zimmermann M, Schrappe M, Welte K, Klein C. Immunosurveillance of childhood ALL: polymorphic interferon-gamma alleles are associated with age at diagnosis and clinical risk groups. Leukemia. (2005) 19:44-8. doi: 10.1038/sj.leu.2403553

71. Colpitts SL, Stonier SW, Stoklasek TA, Root SH, Aguila HL, Schluns KS, et al. Transcriptional regulation of IL-15 expression during hematopoiesis. J Immunol. (2013) 191:3017-24. doi: 10.4049/jimmunol.1301389

72. Cieri N, Camisa B, Cocchiarella F, Forcato M, Oliveira G, Provasi E, et al. IL-7 and IL-15 instruct the generation of human memory stem T cells from naive precursors. Blood. (2013) 121:573-84. doi: 10.1182/blood-2012-05-431718

73. Thiant S, Yakoub-Agha I, Magro L, Trauet J, Coiteux V, Jouet J-P, et al. Plasma levels of IL-7 and IL-15 in the first month after myeloablative BMT are predictive biomarkers of both acute GVHD and relapse. Bone Marrow Transplant. (2010) 45:1546-52. doi: 10.1038/bmt.2010.13

74. Mathew NR, Baumgartner F, Braun L, O'Sullivan D, Thomas S, Waterhouse $\mathrm{M}$, et al. Sorafenib promotes graft-vs.-leukemia activity in mice and humans through IL-15 production in FLT3-ITD-mutant leukemia cells. Nat Med. (2018) 24:282-91. doi: 10.1038/nm.4484

75. Folgiero V, Goffredo BM, Filippini P, Masetti R, Bonanno G, Caruso R, et al. Indoleamine 2,3-dioxygenase 1 (IDO1) activity in leukemia blasts correlates with poor outcome in childhood acute myeloid leukemia. Oncotarget. (2014) 5:2052-64. doi: 10.18632/oncotarget.1504

76. Munn DH, Sharma MD, Baban B, Harding HP, Zhang Y, Ron D, et al. GCN2 kinase in $\mathrm{T}$ cells mediates proliferative arrest and anergy induction in response to indoleamine 2,3-dioxygenase. Immunity. (2005) 22:633-42. doi: 10.1016/j.immuni.2005.03.013

77. Mussai F, De Santo C, Abu-Dayyeh I, Booth S, Quek L, McEwen-Smith $\mathrm{RM}$, et al. Acute myeloid leukemia creates an arginase-dependent immunosuppressive microenvironment. Blood. (2013) 122:749-58. doi: 10.1182/blood-2013-01-480129

78. Serra S, Horenstein AL, Vaisitti T, Brusa D, Rossi D, Laurenti L, et al. CD73-generated extracellular adenosine in chronic lymphocytic leukemia creates local conditions counteracting drug-induced cell death. Blood. (2011) 118:6141-52. doi: 10.1182/blood-2011-08-374728

79. Dulphy N, Henry G, Hemon P, Khaznadar Z, Dombret H, Boissel N, et al. Contribution of CD39 to the immunosuppressive microenvironment of acute myeloid leukaemia at diagnosis. Br J Haematol. (2014) 165:722-5. doi: 10.1111/bjh.12774

80. Vodnala SK, Eil R, Kishton RJ, Sukumar M, Yamamoto TN, Ha N$\mathrm{H}$, et al. $\mathrm{T}$ cell stemness and dysfunction in tumors are triggered by a common mechanism. Science. (2019) 363:eaau0135. doi: 10.1126/science. aau0135

81. Zhou X, Brenner MK. Improving the safety of T-Cell therapies using an inducible caspase-9 gene. Exp Hematol. (2016) 44:1013-9. doi: 10.1016/j.exphem.2016.07.011

82. Greco R, Oliveira G, Stanghellini MTL, Vago L, Bondanza A, Peccatori J, et al. Improving the safety of cell therapy with the TKsuicide gene. Front Pharmacol. (2015) 6:95. doi: 10.3389/fphar.2015.0 0095

83. Anderson BE, McNiff J, Yan J, Doyle H, Mamula M, Shlomchik MJ, et al. Memory CD4+ T cells do not induce graft-vs.-host disease. J Clin Investig. (2003) 112:101-8. doi: 10.1172/JCI17601

84. Muffly L, Sheehan K, Armstrong R, Jensen K, Tate K, Rezvani AR, et al. Infusion of donor-derived $\mathrm{CD} 8+$ memory $\mathrm{T}$ cells for relapse following allogeneic hematopoietic cell transplantation. Blood Adv. (2018) 2:681-90. doi: 10.1182/bloodadvances.2017012104

85. Sebestyen Z, Prinz I, Déchanet-Merville J, Silva-Santos B, Kuball J. Translating gammadelta $(\gamma \delta) \mathrm{T}$ cells and their receptors into cancer cell therapies. Nat Rev Drug Discov. (2019) 24:666-77. doi: 10.1038/s41573-019-0038-z

86. Locatelli F, Merli P, Rutella S. At the bedside: innate immunity as an immunotherapy tool for hematological malignancies. J Leukocyte Biol. (2013) 94:1141-57. doi: 10.1189/jlb.0613343

87. Huang X-J, Liu D-H, Liu K-Y, Xu L-P, Chen H, Han W. Donor lymphocyte infusion for the treatment of leukemia relapse after HLA-mismatched/haploidentical T-cell-replete hematopoietic stem cell transplantation. Haematologica. (2007) 92:414-7. doi: 10.3324/haematol.10570

88. Zeidan AM, Forde PM, Symons H, Chen A, Smith BD, Pratz K, et al. HLA-haploidentical donor lymphocyte infusions for patients with relapsed hematologic malignancies after related HLA-haploidentical bone marrow transplantation. Biol Blood Marrow Transplant. (2014) 20:314-8. doi: 10.1016/j.bbmt.2013.11.020

89. Ghiso A, Raiola AM, Gualandi F, Dominietto A, Varaldo R, Van Lint MT, et al. DLI after haploidentical BMT with post-transplant CY. Bone Marrow Transplant. (2015) 50:56-61. doi: 10.1038/bmt.2014.217

90. Huang X-J, Liu D-H, Liu K-Y, Xu L-P, Chen Y-H, Wang Y, et al. Modified donor lymphocyte infusion after HLA-mismatched/haploidentical T cellreplete hematopoietic stem cell transplantation for prophylaxis of relapse of leukemia in patients with advanced leukemia. J Clin Immunol. (2008) 28:276-83. doi: 10.1007/s10875-007-9166-Z

91. Jedlickova Z, Schmid C, Koenecke C, Hertenstein B, Baurmann H, Schwerdtfeger R, et al. Long-term results of adjuvant donor lymphocyte transfusion in AML after allogeneic stem cell transplantation. Bone Marrow Transplant. (2016) 51:663-7. doi: 10.1038/bmt.2015.234

92. Schmid C, Labopin M, Schaap N, Veelken H, Schleuning M, Stadler M, et al. Prophylactic donor lymphocyte infusion after allogeneic stem cell transplantation in acute leukaemia - a matched pair analysis by the acute leukaemia working party of EBMT. Br J Haematol. (2019) 184:782-7. doi: 10.1111/bjh.15691

93. Rettinger E, Willasch AM, Kreyenberg H, Borkhardt A, Holter W, Kremens B, et al. Preemptive immunotherapy in childhood acute myeloid leukemia for patients showing evidence of mixed chimerism after allogeneic stem cell transplantation. Blood. (2011) 118:5681-8. doi: 10.1182/blood-2011-04-348805

94. Yan C-H, Liu D-H, Liu K-Y, Xu L-P, Liu Y-R, Chen H, et al. Risk stratification-directed donor lymphocyte infusion could reduce relapse of standard-risk acute leukemia patients after allogeneic hematopoietic stem cell transplantation. Blood. (2012) 119:3256-62. doi: 10.1182/blood-2011-09-380386

95. Mo X-D, Zhang X-H, Xu L-P, Wang Y, Yan C-H, Chen $H$, et al. Comparison of outcomes after donor lymphocyte infusion with or without prior chemotherapy for minimal residual disease in acute leukemia/myelodysplastic syndrome after allogeneic hematopoietic stem cell transplantation. Ann Hematol. (2017) 96:829-38. doi: 10.1007/s00277-017-2960-7

96. Schmid C, Labopin M, Nagler A, Bornhäuser M, Finke J, Fassas A, et al. Donor lymphocyte infusion in the treatment of first hematological relapse after allogeneic stem-cell transplantation in adults with acute myeloid leukemia: a retrospective risk factors analysis and comparison with other strategies by the EBMT acute leukemia working party. J Clin Oncol. (2007) 25:4938-45. doi: 10.1200/JCO.2007.11.6053

97. Roux C, Tifratene K, Socié G, Galambrun C, Bertrand Y, Rialland F, et al. Outcome after failure of allogeneic hematopoietic stem cell transplantation in children with acute leukemia: a study by the société francophone de greffe de moelle et de thérapie cellulaire (SFGM-TC). Bone Marrow Transplant. (2017) 52:678-82. doi: 10.1038/bmt.2016.360

98. Miyamoto T, Fukuda T, Nakashima M, Henzan T, Kusakabe S, Kobayashi N, et al. Donor Lymphocyte infusion for relapsed hematological malignancies after unrelated allogeneic bone marrow transplantation facilitated by the Japan marrow donor program. Biol Blood Marrow Transplant. (2017) 23:938-44. doi: 10.1016/j.bbmt.2017.02.012

99. Michallet M, Tanguy ML, Socié G, Thiébaut A, Belhabri A, Milpied $\mathrm{N}$, et al. Second allogeneic haematopoietic stem cell transplantation in relapsed acute and chronic leukaemias for patients who underwent a first allogeneic bone marrow transplantation: a survey of the société française de greffe de moelle (SFGM). Br J Haematol. (2000) 108:400-7. doi: 10.1046/j.1365-2141.2000.01851.x

100. Radich JP, Sanders JE, Buckner CD, Martin PJ, Petersen FB, Bensinger W, et al. Second allogeneic marrow transplantation for patients with recurrent leukemia after initial transplant with total-body irradiation-containing regimens. J Clin Oncol. (1993) 11:304-13. doi: 10.1200/JCO.1993.11.2.304

101. Ghosh A, Smith M, James SE, Davila ML, Velardi E, Argyropoulos $\mathrm{KV}$, et al. Donor CD19 CAR T cells exert potent graft-vs.-lymphoma 
activity with diminished graft-vs.-host activity. Nat Med. (2017) 23:242-9. doi: $10.1038 / \mathrm{nm} .4258$

102. Smith M, Zakrzewski J, James S, Sadelain M. Posttransplant chimeric antigen receptor therapy. Blood. (2018) 131:1045-52. doi: 10.1182/blood-2017-08-752121

103. Porter DL, Levine BL, Kalos M, Bagg A, June CH. Chimeric antigen receptormodified T cells in chronic lymphoid leukemia. N Engl J Med. (2011) 365:725-33. doi: 10.1056/NEJMoa1103849

104. Kochenderfer JN, Dudley ME, Feldman SA, Wilson WH, Spaner DE, Maric I, S et al. B-cell depletion and remissions of malignancy along with cytokine-associated toxicity in a clinical trial of anti-CD19 chimeric-antigen-receptor-transduced T cells. Blood. (2012) 119:2709-20. doi: 10.1182/blood-2011-10-384388

105. Grupp SA, Kalos M, Barrett D, Aplenc R, Porter DL, Rheingold SR, et al. Chimeric antigen receptor-modified T cells for acute lymphoid leukemia. $N$ Engl J Med. (2013) 368:1509-18. doi: 10.1056/NEJMoa1215134

106. Schuster SJ, Svoboda J, Chong EA, Nasta SD, Mato AR, Anak Ö, et al. Chimeric antigen receptor T cells in refractory B-cell lymphomas. N Engl J Med. (2017) 377:2545-54. doi: 10.1056/NEJMoa1708566

107. Schuster SJ, Bishop MR, Tam CS, Waller EK, Borchmann P, McGuirk JP, et al. Tisagenlecleucel in adult relapsed or refractory diffuse large B-cell lymphoma. N Engl J Med. (2019) 380:45-56. doi: 10.1056/NEJMoa1804980

108. Park JH, Rivière I, Gonen M, Wang X, Sénéchal B, Curran KJ, et al. Longterm follow-up of CD19 CAR therapy in acute lymphoblastic leukemia. $N$ Engl J Med. (2018) 378:449-59. doi: 10.1056/NEJMoa1709919

109. Kochenderfer JN, Dudley ME, Carpenter RO, Kassim SH, Rose JJ, Telford WG, et al. Donor-derived CD19-targeted T cells cause regression of malignancy persisting after allogeneic hematopoietic stem cell transplantation. Blood. (2013) 122:4129-39. doi: 10.1182/blood-2013-08-519413

110. Brudno JN, Somerville RPT, Shi V, Rose JJ, Halverson DC, Fowler DH, et al. Allogeneic $\mathrm{T}$ cells that express an anti-CD19 chimeric antigen receptor induce remissions of $\mathrm{B}$-cell malignancies that progress after allogeneic hematopoietic stem-cell transplantation without causing graft-vs.host disease. J Clin Oncol. (2016) 34:1112-21. doi: 10.1200/JCO.2015.64.5929

111. Kebriaei P, Singh H, Huls MH, Figliola MJ, Bassett R, Olivares S, et al. Phase I trials using sleeping beauty to generate CD19-specific CAR T cells. J Clin Invest. (2016) 126:3363-76. doi: 10.1172/JCI86721

112. Jia H, Wang Z, Wang Y, Liu Y, Dai H, Tong C, et al. Haploidentical CD19/CD22 bispecific CAR-T cells induced MRD-negative remission in a patient with relapsed and refractory adult B-ALL after haploidentical hematopoietic stem cell transplantation. J Hematol Oncol. (2019) 12:57. doi: 10.1186/s13045-019-0741-6

113. Hu Y, Wang J, Wei G, Yu J, Luo Y, Shi J, et al. A retrospective comparison of allogenic and autologous chimeric antigen receptor $\mathrm{T}$ cell therapy targeting CD19 in patients with relapsed/refractory acute lymphoblastic leukemia. Bone Marrow Transplant. (2019) 54:1208-17. doi: 10.1038/s41409-018-0403-2

114. Eyquem J, Mansilla-Soto J, Giavridis T, van der Stegen SJC, Hamieh $\mathrm{M}$, Cunanan $\mathrm{KM}$, et al. Targeting a CAR to the TRAC locus with CRISPR/Cas9 enhances tumour rejection. Nature. (2017) 543:113-7. doi: 10.1038/nature21405

115. Rotolo A, Caputo VS, Holubova M, Baxan N, Dubois O, Chaudhry MS, et al. Enhanced anti-lymphoma activity of CAR19-iNKT cells underpinned by dual CD19 and CD1d targeting. Cancer Cell. (2018) 34:596-610.e11. doi: 10.1016/j.ccell.2018.08.017

116. Liu E, Tong Y, Dotti G, Shaim H, Savoldo B, Mukherjee M, et al. Cord blood NK cells engineered to express IL-15 and a CD19-targeted CAR show longterm persistence and potent antitumor activity. Leukemia. (2018) 32:520-31. doi: 10.1038/leu.2017.226

117. Offner S, Hofmeister R, Romaniuk A, Kufer P, Baeuerle PA. Induction of regular cytolytic $\mathrm{T}$ cell synapses by bispecific single-chain antibody constructs on MHC class I-negative tumor cells. Mol Immunol. (2006) 43:763-71. doi: 10.1016/j.molimm.2005.03.007

118. Zhukovsky EA, Morse RJ, Maus MV. Bispecific antibodies and CARs: generalized immunotherapeutics harnessing $\mathrm{T}$ cell redirection. Curr Opin Immunol. (2016) 40:24-35. doi: 10.1016/j.coi.2016. 02.006
119. Haas C, Krinner E, Brischwein K, Hoffmann P, Lutterbüse R, Schlereth B, et al. Mode of cytotoxic action of T cell-engaging BiTE antibody MT110. Immunobiology. (2009) 214:441-53. doi: 10.1016/j.imbio.2008.11.014

120. Hornig N, Reinhardt K, Kermer V, Kontermann RE, Müller D. Evaluating combinations of costimulatory antibody-ligand fusion proteins for targeted cancer immunotherapy. Cancer Immunol Immunother. (2013) 62:1369-80. doi: 10.1007/s00262-013-1441-7

121. Hornig N, Kermer V, Frey K, Diebolder P, Kontermann RE, Müller D. Combination of a bispecific antibody and costimulatory antibody-ligand fusion proteins for targeted cancer immunotherapy. J Immunother. (2012) 35:418-29. doi: 10.1097/CJI.0b013e3182594387

122. Arndt C, Feldmann A, von Bonin M, Cartellieri M, Ewen E-M, Koristka S, et al. Costimulation improves the killing capability of $\mathrm{T}$ cells redirected to tumor cells expressing low levels of CD33: description of a novel modular targeting system. Leukemia. (2014) 28:59-69. doi: 10.1038/leu.2013.243

123. Köhnke T, Krupka C, Tischer J, Knösel T, Subklewe M. Increase of PD-L1 expressing B-precursor ALL cells in a patient resistant to the CD19/CD3bispecific T cell engager antibody blinatumomab. J Hematol Oncol. (2015) 8:111. doi: $10.1186 /$ s13045-015-0213-6

124. Laszlo GS, Gudgeon CJ, Harrington KH, Walter RB. T-cell ligands modulate the cytolytic activity of the CD33/CD3 BiTE antibody construct, AMG 330 . Blood Cancer J. (2015) 5:e340. doi: 10.1038/bcj.2015.68

125. Yano H, Thakur A, Tomaszewski EN, Choi M, Deol A, Lum LG. Ipilimumab augments antitumor activity of bispecific antibody-armed T cells. J Transl Med. (2014) 12:191. doi: 10.1186/1479-5876-12-191

126. Frikeche J, Clavert A, Delaunay J, Brissot E, Grégoire M, Gaugler $B$, et al. Impact of the hypomethylating agent 5-azacytidine on dendritic cells function. Exp Hematol. (2011) 39:1056-63. doi: 10.1016/j.exphem.2011.08.004

127. Pinto A, Maio M, Attadia V, Zappacosta S, Cimino R. Modulation of HLA-DR antigens expression in human myeloid leukaemia cells by cytarabine and 5-aza-2'-deoxycytidine. Lancet. (1984) 2:867-8. doi: 10.1016/S0140-6736(84)90900-0

128. Flotho C, Claus R, Batz C, Schneider M, Sandrock I, Ihde S, et al. The DNA methyltransferase inhibitors azacitidine, decitabine and zebularine exert differential effects on cancer gene expression in acute myeloid leukemia cells. Leukemia. (2009) 23:1019-28. doi: 10.1038/leu.2008.397

129. Atanackovic D, Luetkens T, Kloth B, Fuchs G, Cao Y, Hildebrandt Y, et al. Cancer-testis antigen expression and its epigenetic modulation in acute myeloid leukemia. Am J Hematol. (2011) 86:918-22. doi: 10.1002/ajh.22141

130. Goodyear O, Agathanggelou A, Novitzky-Basso I, Siddique S, McSkeane T, Ryan G, et al. Induction of a CD8+ T-cell response to the MAGE cancer testis antigen by combined treatment with azacitidine and sodium valproate in patients with acute myeloid leukemia and myelodysplasia. Blood. (2010) 116:1908-18. doi: 10.1182/blood-2009-11-249474

131. Goodyear OC, Dennis M, Jilani NY, Loke J, Siddique S, Ryan G, et al. Azacitidine augments expansion of regulatory $\mathrm{T}$ cells after allogeneic stem cell transplantation in patients with acute myeloid leukemia (AML). Blood. (2012) 119:3361-9. doi: 10.1182/blood-2011-09-377044

132. Sánchez-Abarca LI, Gutierrez-Cosio S, Santamaría C, CaballeroVelazquez T, Blanco B, Herrero-Sánchez C, et al. Immunomodulatory effect of 5-azacytidine. (5-azaC): potential role in the transplantation setting. Blood. (2010) 115:107-21. doi: 10.1182/blood-2009-03-21 0393

133. Almstedt M, Blagitko-Dorfs N, Duque-Afonso J, Karbach J, Pfeifer D, Jäger $\mathrm{E}$, et al. The DNA demethylating agent 5-aza-2'deoxycytidine induces expression of NY-ESO-1 and other cancer/testis antigens in myeloid leukemia cells. Leuk Res. (2010) 34:899-905. doi: 10.1016/j.leukres.2010.02.004

134. Guo ZS, Hong JA, Irvine KR, Chen GA, Spiess PJ, Liu Y, et al. De novo induction of a cancer/testis antigen by 5-aza-2'-deoxycytidine augments adoptive immunotherapy in a murine tumor model. Cancer Res. (2006) 66:1105-13. doi: 10.1158/0008-5472.CAN-05-3020

135. Weber J, Salgaller M, Samid D, Johnson B, Herlyn M, Lassam N, et al. Expression of the MAGE-1 tumor antigen is up-regulated by the demethylating agent 5-aza-2'-deoxycytidine. Cancer Res. (1994) 54:1766-71.

136. Dubovsky JA, McNeel DG, Powers JJ, Gordon J, Sotomayor EM, Pinilla-Ibarz JA. Treatment of chronic lymphocytic leukemia with a hypomethylating 
agent induces expression of NXF2, an immunogenic cancer testis antigen. Clin Cancer Res. (2009) 15:3406-15. doi: 10.1158/1078-0432.CCR-08-2099

137. Fonsatti E, Nicolay HJM, Sigalotti L, Calabrò L, Pezzani L, Colizzi F, et al. Functional up-regulation of human leukocyte antigen class I antigens expression by 5 -aza-2'-deoxycytidine in cutaneous melanoma: immunotherapeutic implications. Clin Cancer Res. (2007) 13:3333-8. doi: 10.1158/1078-0432.CCR-06-3091

138. Chiappinelli KB, Strissel PL, Desrichard A, Li H, Henke C, Akman B, et al. Inhibiting DNA methylation causes an interferon response in cancer via dsRNA including endogenous retroviruses. Cell. (2015) 162:974-86. doi: 10.1016/j.cell.2015.07.011

139. Roulois D, Loo Yau H, Singhania R, Wang Y, Danesh A, Shen SY, et al. DNA-Demethylating agents target colorectal cancer cells by inducing viral mimicry by endogenous transcripts. Cell. (2015) 162:961-73. doi: 10.1016/j.cell.2015.07.056

140. Parker BS, Rautela J, Hertzog PJ. Antitumour actions of interferons: implications for cancer therapy. Nat Rev Cancer. (2016) 16:131-44. doi: $10.1038 / \mathrm{nrc} .2016 .14$

141. Yang H, Bueso-Ramos C, DiNardo C, Estecio MR, Davanlou M, Geng QR, et al. Expression of PD-L1, PD-L2, PD-1 and CTLA4 in myelodysplastic syndromes is enhanced by treatment with hypomethylating agents. Leukemia. (2014) 28:1280-8. doi: 10.1038/leu.2013.355

142. Ørskov AD, Treppendahl MB, Skovbo A, Holm MS, Friis LS, Hokland M, et al. Hypomethylation and up-regulation of PD-1 in T cells by azacytidine in MDS/AML patients: a rationale for combined targeting of PD-1 and DNA methylation. Oncotarget. (2015) 6:9612-26. doi: 10.18632/oncotarget.3324

143. Jabbour E, Giralt S, Kantarjian H, Garcia-Manero G, Jagasia M, Kebriaei P, et al. Low-dose azacitidine after allogeneic stem cell transplantation for acute leukemia. Cancer. (2009) 115:1899-905. doi: 10.1002/cncr.24198

144. Schroeder T, Czibere A, Platzbecker U, Bug G, Uharek L, Luft T, et al. Azacitidine and donor lymphocyte infusions as first salvage therapy for relapse of AML or MDS after allogeneic stem cell transplantation. Leukemia. (2013) 27:1229-35. doi: 10.1038/leu.2013.7

145. Schroeder T, Rachlis E, Bug G, Stelljes M, Klein S, Steckel NK, Wet al. Treatment of acute myeloid leukemia or myelodysplastic syndrome relapse after allogeneic stem cell transplantation with azacitidine and donor lymphocyte infusions-a retrospective multicenter analysis from the German cooperative transplant study group. Biol Blood Marrow Transplant. (2015) 21:653-60. doi: 10.1016/j.bbmt.2014.12.016

146. Craddock C, Labopin M, Robin M, Finke J, Chevallier P, Yakoub-Agha I, et al. Clinical activity of azacitidine in patients who relapse after allogeneic stem cell transplantation for acute myeloid leukemia. Haematologica. (2016) 101:879-83. doi: 10.3324/haematol.2015.140996

147. Ghobadi A, Choi J, Fiala MA, Fletcher T, Liu J, Eissenberg LG, et al. Phase I study of azacitidine following donor lymphocyte infusion for relapsed acute myeloid leukemia post allogeneic stem cell transplantation. Leuk Res. (2016) 49:1-6. doi: 10.1016/j.leukres.2016.07.010

148. Woo J, Deeg HJ, Storer B, Yeung C, Fang M, Mielcarek M, et al. Factors determining responses to azacitidine in patients with myelodysplastic syndromes and acute myeloid leukemia with early post-transplantation relapse: a prospective trial. Biol Blood Marrow Transplant. (2017) 23:176-9. doi: 10.1016/j.bbmt.2016.10.016

149. Choi SW, Braun T, Chang L, Ferrara JLM, Pawarode A, Magenau JM, et al. Vorinostat plus tacrolimus and mycophenolate to prevent graftvs.-host disease after related-donor reduced-intensity conditioning allogeneic haemopoietic stem-cell transplantation: a phase $1 / 2$ trial. Lancet Oncol. (2014) 15:87-95. doi: 10.1016/S1470-2045(13)7 0512-6

150. Choi SW, Gatza E, Hou G, Sun Y, Whitfield J, Song Y, et al. Histone deacetylase inhibition regulates inflammation and enhances tregs after allogeneic hematopoietic cell transplantation in humans. Blood. (2015) 125:815-9. doi: 10.1182/blood-2014-10-605238

151. Bug G, Burchert A, Wagner E-M, Kröger N, Berg T, Güller S, et al. Phase I/II study of the deacetylase inhibitor panobinostat after allogeneic stem cell transplantation in patients with high-risk MDS or AML (PANOBEST trial). Leukemia. (2017) 31:2523-5. doi: 10.1038/leu.2017.242

152. Cornelissen JJ, van Norden Y, van Gelder M, Breems DA, Maertens J, JongenLavrencic M, et al. Early post-transplant epigenetic therapy by panobinostat and decitabine followed by Donor Lymphocyte Infusion (DLI): interim results of the HOVON-116 phase I/II feasibility study in poor-risk AML recipients of allogeneic stem cell transplantation (alloHSCT). Blood J. (2016) 128:832. doi: 10.1182/blood.V128.22.832.832

153. Greil R, Hutterer E, Hartmann TN, Pleyer L. Reactivation of dormant anti-tumor immunity - a clinical perspective of therapeutic immune checkpoint modulation. Cell Commun Signal. (2017) 15:5. doi: $10.1186 / \mathrm{s} 12964-016-0155-9$

154. Pardoll DM. The blockade of immune checkpoints in cancer immunotherapy. Nat Rev Cancer. (2012) 12:252-64. doi: 10.1038/nrc3239

155. Chen L, Flies DB. Molecular mechanisms of $\mathrm{T}$ cell co-stimulation and co-inhibition. Nat Rev Immunol. (2013) 13:227-42. doi: 10.1038/nri3405

156. Bashey A, Medina B, Corringham S, Pasek M, Carrier E, Vrooman L, et al. CTLA4 blockade with ipilimumab to treat relapse of malignancy after allogeneic hematopoietic cell transplantation. Blood. (2009) 113:1581-8. doi: 10.1182/blood-2008-07-168468

157. Davids MS, Kim HT, Bachireddy P, Costello C, Liguori R, Savell A, et al. Ipilimumab for patients with relapse after allogeneic transplantation. $N$ Engl J Med. (2016) 375:143-53. doi: 10.1056/NEJMoa1601202

158. Albring JC, Inselmann S, Sauer T, Schliemann C, Altvater B, Kailayangiri $\mathrm{S}$, et al. PD-1 checkpoint blockade in patients with relapsed AML after allogeneic stem cell transplantation. Bone Marrow Transplant. (2017) 52:317-20. doi: 10.1038/bmt.2016.274

159. McDuffee E, Aue G, Cook L, Ramos-Delgado C, Shalabi R, Worthy $\mathrm{T}$, et al. Tumor regression concomitant with steroid-refractory GvHD highlights the pitfalls of PD-1 blockade following allogeneic hematopoietic stem cell transplantation. Bone Marrow Transplant. (2017) 52:759-61. doi: 10.1038/bmt.2016.346

160. Onizuka M, Kojima M, Matsui K, Machida S, Toyosaki M, Aoyama Y, et al. Successful treatment with low-dose nivolumab in refractory hodgkin lymphoma after allogeneic stem cell transplantation. Int J Hematol. (2017) 106:141-5. doi: 10.1007/s12185-017-2181-9

161. Herbaux C, Gauthier J, Brice P, Drumez E, Ysebaert L, Doyen $\mathrm{H}$, et al. Efficacy and tolerability of nivolumab after allogeneic transplantation for relapsed hodgkin lymphoma. Blood. (2017) 129:2471-8. doi: 10.1182/blood-2016-11-749556

162. Haverkos BM, Abbott D, Hamadani M, Armand P, Flowers ME, Merryman $\mathrm{R}$, et al. PD-1 blockade for relapsed lymphoma post-allogeneic hematopoietic cell transplant: high response rate but frequent GVHD. Blood. (2017) 130:221-8. doi: 10.1182/blood-2017-01-761346

163. Wang L, Amoozgar Z, Huang J, Saleh MH, Xing D, Orsulic S, et al. Decitabine enhances lymphocyte migration and function and synergizes with CTLA-4 blockade in a murine ovarian cancer model. Cancer Immunol Res. (2015) 3:1030-41. doi: 10.1158/2326-6066.CIR-15-0073

164. Daver N, Boddu P, Garcia-Manero G, Yadav SS, Sharma P, Allison J, et al. Hypomethylating agents in combination with immune checkpoint inhibitors in acute myeloid leukemia and myelodysplastic syndromes. Leukemia. (2018) 32:1094-105. doi: 10.1038/s41375-018-0070-8

165. Dear AE. Epigenetic modulators and the new immunotherapies. $N$ Engl $J$ Med. (2016) 374:684-6. doi: 10.1056/NEJMcibr1514673

166. Daver N, Garcia-Manero G, Basu S, Boddu PC, Alfayez M, Cortes JE, et al. Efficacy, safety, and biomarkers of response to azacitidine and nivolumab in relapsed/refractory acute myeloid leukemia: a nonrandomized, open-label, phase II study. Cancer Discov. (2019) 9:370-83. doi: 10.1158/2159-8290.CD-18-0774

167. Ettinghausen SE, Lipford EH, Mulé JJ, Rosenberg SA. Recombinant interleukin 2 stimulates in vivo proliferation of adoptively transferred lymphokine-activated killer (LAK) cells. J Immunol. (1985) 135:3623-35.

168. Alatrash G, Jakher H, Stafford PD, Mittendorf EA. Cancer immunotherapies, their safety and toxicity. Expert Opin Drug Saf. (2013) 12:631-45. doi: $10.1517 / 14740338.2013 .795944$

169. Foa R, Guarini A, Gansbacher B. IL2 treatment for cancer: from biology to gene therapy. Br J Cancer. (1992) 66:992-8. doi: 10.1038/bjc.1992.400

170. Buyse M, Squifflet P, Lange BJ, Alonzo TA, Larson RA, Kolitz JE, et al. Individual patient data meta-analysis of randomized trials evaluating IL-2 monotherapy as remission maintenance therapy in acute myeloid leukemia. Blood. (2011) 117:7007-13. doi: 10.1182/blood-2011-02337725 
171. Acuto O, Di Bartolo V, Michel F. Tailoring T-cell receptor signals by proximal negative feedback mechanisms. Nat Rev Immunol. (2008) 8:699712. doi: 10.1038/nri2397

172. Ustun C, Miller JS, Munn DH, Weisdorf DJ, Blazar BR. Regulatory T cells in acute myelogenous leukemia: is it time for immunomodulation? Blood. (2011) 118:5084-95. doi: 10.1182/blood-2011-07-365817

173. Kolitz JE, George SL, Benson DM, Maharry K, Marcucci G, Vij R, et al. Recombinant interleukin-2 in patients aged younger than 60 years with acute myeloid leukemia in first complete remission: results from cancer and leukemia group B 19808. Cancer. (2014) 120:1010-7. doi: 10.1002/cncr.28516

174. Platanias LC. Interferons and their antitumor properties. J Interferon Cytokine Res. (2013) 33:143-4. doi: 10.1089/jir.2013.0019

175. Le Bon A, Tough DF. Type I interferon as a stimulus for cross-priming. Cytokine Growth Factor Rev. (2008) 19:33-40. doi: 10.1016/j.cytogfr.2007.10.007

176. Papewalis C, Jacobs B, Wuttke M, Ullrich E, Baehring T, Fenk R, et al. IFNalpha skews monocytes into CD56+-expressing dendritic cells with potent functional activities in vitro and in vivo. J Immunol. (2008) 180:1462-70. doi: 10.4049/jimmunol.180.3.1462

177. Bekisz J, Sato Y, Johnson C, Husain SR, Puri RK, Zoon KC. Immunomodulatory effects of interferons in malignancies. J Interferon Cytokine Res. (2013) 33:154-61. doi: 10.1089/jir.2012.0167

178. Anguille S, Lion E, Willemen Y, Van Tendeloo VFI, Berneman ZN, Smits ELJM. Interferon- $\alpha$ in acute myeloid leukemia: an old drug revisited. Leukemia. (2011) 25:739-48. doi: 10.1038/leu.2010.324

179. Colamonici OR, Domanski P, Platanias LC, Diaz MO. Correlation between interferon (IFN) alpha resistance and deletion of the IFN alpha/beta genes in acute leukemia cell lines suggests selection against the IFN system. Blood. (1992) 80:744-9. doi: 10.1182/blood.V80.3.744.bloodjournal803744

180. Smits ELJM, Anguille S, Berneman ZN. Interferon $\alpha$ may be back on track to treat acute myeloid leukemia. Oncoimmunology. (2013) 2:e23619. doi: 10.4161/onci.23619

181. Robb RJ, Kreijveld E, Kuns RD, Wilson YA, Olver SD, Don ALJ, et al. Type IIFNs control GVHD and GVL responses after transplantation. Blood. (2011) 118:3399-409. doi: 10.1182/blood-2010-12-325746

182. Steel JC, Waldmann TA, Morris JC. Interleukin-15 biology and its therapeutic implications in cancer. Trends Pharmacol Sci. (2012) 33:35-41. doi: 10.1016/j.tips.2011.09.004

183. Conlon KC, Lugli E, Welles HC, Rosenberg SA, Fojo AT, Morris JC, et al. Redistribution, hyperproliferation, activation of natural killer cells and CD8 T cells, and cytokine production during first-in-human clinical trial of recombinant human interleukin-15 in patients with cancer. J Clin Oncol. (2015) 33:74-82. doi: 10.1200/JCO.2014.57.3329

184. Klebanoff CA, Finkelstein SE, Surman DR, Lichtman MK, Gattinoni L, Theoret MR, et al. IL-15 enhances the in vivo antitumor activity of tumorreactive CD8+ T cells. Proc Natl Acad Sci USA. (2004) 101:1969-74. doi: 10.1073/pnas.0307298101

185. Cieri N, Oliveira G, Greco R, Forcato M, Taccioli C, Cianciotti B, et al. Generation of human memory stem $\mathrm{T}$ cells after haploidentical Treplete hematopoietic stem cell transplantation. Blood. (2015) 125:2865-74. doi: 10.1182/blood-2014-11-608539

186. Ring AM, Lin J-X, Feng D, Mitra S, Rickert M, Bowman GR, et al. Mechanistic and structural insight into the functional dichotomy between IL-2 and IL-15. Nat Immunol. (2012) 13:1187-95. doi: 10.1038/ni.2449

187. Romee R, Cooley S, Berrien-Elliott MM, Westervelt P, Verneris MR, Wagner JE, et al. First-in-human phase 1 clinical study of the IL-15 superagonist complex ALT-803 to treat relapse after transplantation. Blood. (2018) 131:2515-27. doi: 10.1182/blood-2017-12-823757

188. Escobar G, Barbarossa L, Barbiera G, Norelli M, Genua M, Ranghetti A, et al. Interferon gene therapy reprograms the leukemia microenvironment inducing protective immunity to multiple tumor antigens. Nat Commun. (2018) 9:2896. doi: 10.1038/s41467-018-05315-0

189. Pastor F, Berraondo P, Etxeberria I, Frederick J, Sahin U, Gilboa E, et al. An RNA toolbox for cancer immunotherapy. Nat Rev Drug Discov. (2018) 17:751-67. doi: 10.1038/nrd.2018.132

190. Olavarria E, Siddique S, Griffiths MJ, Avery S, Byrne JL, Piper KP, et al. Posttransplantation imatinib as a strategy to postpone the requirement for immunotherapy in patients undergoing reduced-intensity allografts for chronic myeloid leukemia. Blood. (2007) 110:4614-7. doi: 10.1182/blood-2007-04-082990

191. Ribera J-M, Oriol A, González M, Vidriales B, Brunet S, Esteve J, et al. Concurrent intensive chemotherapy and imatinib before and after stem cell transplantation in newly diagnosed Philadelphia chromosomepositive acute lymphoblastic leukemia. final results of the CSTIBES02 trial. Haematologica. (2010) 95:87-95. doi: 10.3324/haematol.2009.0 11221

192. Shin JY, Hu W, Naramura M, Park CY. High c-Kit expression identifies hematopoietic stem cells with impaired self-renewal and megakaryocytic bias. J Exp Med. (2014) 211:217-31. doi: 10.1084/jem.20 131128

193. Bodine DM, Seidel NE, Zsebo KM, Orlic D. In vivo administration of stem cell factor to mice increases the absolute number of pluripotent hematopoietic stem cells. Blood. (1993) 82:445-55. doi: 10.1182/blood.V82.2.445.445

194. Thorén LA, Liuba K, Bryder D, Nygren JM, Jensen CT, Qian H, et al. Kit regulates maintenance of quiescent hematopoietic stem cells. J Immunol. (2008) 180:2045-53. doi: 10.4049/jimmunol.180.4.2045

195. Zitvogel L, Rusakiewicz S, Routy B, Ayyoub M, Kroemer G. Immunological off-target effects of imatinib. Nat Rev Clin Oncol. (2016) 13:431-46. doi: 10.1038/nrclinonc.2016.41

196. Appel S, Rupf A, Weck MM, Schoor O, Brümmendorf TH, Weinschenk T, et al. Effects of imatinib on monocyte-derived dendritic cells are mediated by inhibition of nuclear factor-kappaB and Akt signaling pathways. Clin Cancer Res. (2005) 11:1928-40. doi: 10.1158/1078-0432.CCR-04-1713

197. Appel S, Boehmler AM, Grünebach F, Müller MR, Rupf A, Weck MM, et al. Imatinib mesylate affects the development and function of dendritic cells generated from CD34+ peripheral blood progenitor cells. Blood. (2004) 103:538-44. doi: 10.1182/blood-2003-03-0975

198. Taïeb J, Maruyama K, Borg C, Terme M, Zitvogel L. Imatinib mesylate impairs Flt3L-mediated dendritic cell expansion and antitumor effects in vivo. Blood. (2004) 103:1966-7. doi: 10.1182/blood-2003-103475

199. Boissel N, Rousselot P, Raffoux E, Cayuela J-M, Maarek O, Charron D, et al. Defective blood dendritic cells in chronic myeloid leukemia correlate with high plasmatic VEGF and are not normalized by imatinib mesylate. Leukemia. (2004) 18:1656-61. doi: 10.1038/sj.leu.2403474

200. van Dongen M, Savage NDL, Jordanova ES, Briaire-de Bruijn IH, Walburg KV, Ottenhoff THM, et al. Anti-inflammatory M2 type macrophages characterize metastasized and tyrosine kinase inhibitortreated gastrointestinal stromal tumors. Int J Cancer. (2010) 127:899-909. doi: 10.1002/ijc. 25113

201. Cavnar MJ, Zeng S, Kim TS, Sorenson EC, Ocuin LM, Balachandran VP, et al. KIT oncogene inhibition drives intratumoral macrophage M2 polarization. $J$ Exp Med. (2013) 210:2873-86. doi: 10.1084/jem.20130875

202. Seggewiss R, Loré K, Greiner E, Magnusson MK, Price DA, Douek $\mathrm{DC}$, et al. Imatinib inhibits T-cell receptor-mediated T-cell proliferation and activation in a dose-dependent manner. Blood. (2005) 105:2473-9. doi: 10.1182/blood-2004-07-2527

203. Gao H, Lee B-N, Talpaz M, Donato NJ, Cortes JE, Kantarjian HM, et al. Imatinib mesylate suppresses cytokine synthesis by activated CD4 T cells of patients with chronic myelogenous leukemia. Leukemia. (2005) 19:1905-11. doi: 10.1038/sj.leu.2403933

204. de Lavallade H, Khoder A, Hart M, Sarvaria A, Sekine T, Alsuliman A, et al. Tyrosine kinase inhibitors impair B-cell immune responses in CML through off-target inhibition of kinases important for cell signaling. Blood. (2013) 122:227-38. doi: 10.1182/blood-2012-11-465039

205. Steegmann JL, Moreno G, Aláez C, Osorio S, Granda A, de la Cámara R, et al. Chronic myeloid leukemia patients resistant to or intolerant of interferon alpha and subsequently treated with imatinib show reduced immunoglobulin levels and hypogammaglobulinemia. Haematologica. (2003) 88:762-8.

206. Carulli G, Cannizzo E, Ottaviano V, Cervetti G, Buda G, Galimberti S, et al. Abnormal phenotype of bone marrow plasma cells in patients with chronic myeloid leukemia undergoing therapy with imatinib. Leuk Res. (2010) 34:1336-9. doi: 10.1016/j.leukres.2010.01.012

207. Balachandran VP, Cavnar MJ, Zeng S, Bamboat ZM, Ocuin LM, Obaid H, et al. Imatinib potentiates antitumor $\mathrm{T}$ cell responses in gastrointestinal 
stromal tumor through the inhibition of ido. Nat Med. (2011) 17:1094-100. doi: $10.1038 / \mathrm{nm} .2438$

208. Larmonier N, Janikashvili N, LaCasse CJ, Larmonier CB, Cantrell J, Situ E, et al. Imatinib mesylate inhibits $\mathrm{CD} 4+\mathrm{CD} 25+$ regulatory $\mathrm{T}$ cell activity and enhances active immunotherapy against BCR-ABL- tumors. J Immunol. (2008) 181:6955-63. doi: 10.4049/jimmunol.181.10.6955

209. Giallongo C, Parrinello N, Tibullo D, La Cava P, Romano A, Chiarenza A, et al. Myeloid derived suppressor cells (MDSCs) are increased and exert immunosuppressive activity together with polymorphonuclear leukocytes (PMNs) in chronic myeloid leukemia patients. PLoS ONE. (2014) 9:e101848. doi: 10.1371/journal.pone. 0101848

210. Christiansson L, Söderlund S, Mangsbo S, Hjorth-Hansen H, Höglund M, Markevärn B, et al. The tyrosine kinase inhibitors imatinib and dasatinib reduce myeloid suppressor cells and release effector lymphocyte responses. Mol Cancer Ther. (2015) 14:1181-91. doi: 10.1158/1535-7163.MCT-14-0849

211. Christiansson L, Söderlund S, Svensson E, Mustjoki S, Bengtsson M, Simonsson B, et al. Increased level of myeloid-derived suppressor cells, programmed death receptor ligand 1/programmed death receptor 1 , and soluble CD25 in Sokal high risk chronic myeloid leukemia. PLoS ONE. (2013) 8:e55818. doi: 10.1371/journal.pone.0055818

212. Legros L, Bourcier C, Jacquel A, Mahon F-X, Cassuto J-P, Auberger P, et al. Imatinib mesylate (STI571) decreases the vascular endothelial growth factor plasma concentration in patients with chronic myeloid leukemia. Blood. (2004) 104:495-501. doi: 10.1182/blood-2003-08-2695

213. Legros L, Guilhot J, Huault S, Mahon FX, Preudhomme C, Guilhot $\mathrm{F}$, et al. Interferon decreases VEGF levels in patients with chronic myeloid leukemia treated with imatinib. Leuk Res. (2014) 38:662-5. doi: 10.1016/j.leukres.2014.01.010

214. Chen CI-U, Maecker HT, Lee PP. Development and dynamics of robust Tcell responses to CML under imatinib treatment. Blood. (2008) 111:5342-9. doi: 10.1182/blood-2007-12-128397

215. Riva G, Luppi M, Barozzi P, Quadrelli C, Basso S, Vallerini D, et al. Emergence of BCR-ABL-specific cytotoxic $\mathrm{T}$ cells in the bone marrow of patients with $\mathrm{Ph}+$ acute lymphoblastic leukemia during long-term imatinib mesylate treatment. Blood. (2010) 115:1512-8. doi: 10.1182/blood-2009-06-230391

216. Riva G, Luppi M, Lagreca I, Barozzi P, Quadrelli C, Vallerini D, et al. Longterm molecular remission with persistence of BCR-ABL1-specific cytotoxic
T cells following imatinib withdrawal in an elderly patient with philadelphiapositive ALL. Br J Haematol. (2014) 164:299-302. doi: 10.1111/bjh. 12612

217. Ohyashiki K, Katagiri S, Tauchi T, Ohyashiki JH, Maeda Y, Matsumura I, et al. Increased natural killer cells and decreased CD3(+)CD8(+)CD62L $(+)$ $\mathrm{T}$ cells in CML patients who sustained complete molecular remission after discontinuation of imatinib. Br J Haematol. (2012) 157:254-6. doi: 10.1111/j.1365-2141.2011.08939.x

218. Hsiao M, Martynova A, Yaghmour G, Foss C. Investigating the relationship between $\mathrm{CD} 34+$ and $\mathrm{CD} 3+$ cell doses, one-year graft-vs.-relapse-freesurvival, graft-vs.-host disease, and overall survival in haploidentical hematopoietic stem cell transplantation: a single center experience. Blood. (2019) 134:2051. doi: 10.1182/blood-2019-129647

219. Impola U, Larjo A, Salmenniemi U, Putkonen M, Itälä-Remes M, Partanen J. Graft immune cell composition associates with clinical outcome of allogeneic hematopoietic stem cell transplantation in patients with AML. Front Immunol. (2016) 7:523. doi: 10.3389/fimmu.2016.00523

220. Fisher SA, Lamikanra A, Dorée C, Gration B, Tsang P, Danby RD, et al. Increased regulatory $\mathrm{T}$ cell graft content is associated with improved outcome in haematopoietic stem cell transplantation: a systematic review. Br J Haematol. (2017) 176:448-63. doi: 10.1111/bjh. 14433

Conflict of Interest: LV received research funding from GenDx (Utrecht, The Netherlands) and Moderna Therapeutics (Cambridge, MA, USA).

The remaining authors declare that the research was conducted in the absence of any commercial or financial relationships that could be construed as a potential conflict of interest.

Copyright ( 2020 Rovatti, Gambacorta, Lorentino, Ciceri and Vago. This is an open-access article distributed under the terms of the Creative Commons Attribution License (CC BY). The use, distribution or reproduction in other forums is permitted, provided the original author(s) and the copyright owner(s) are credited and that the original publication in this journal is cited, in accordance with accepted academic practice. No use, distribution or reproduction is permitted which does not comply with these terms. 